\title{
Kultura pracy w zawodzie specjalisty PR w telewizji
}

\section{Working Culture in the Profession of PR Specialist in Television}

\author{
Sylwia Szostak
}

\begin{abstract}
Abstrakt
Kampanie promocyjne seriali wzbudzają zainteresowanie swoim rozmachem, kreatywnością i oryginalnością. Jednak bardzo mało wiemy o ludziach, którzy te działania promocyjne planują, i o instytucjonalnym kontekście ich pracy. Niniejszy artykuł zatem sprzyja namysłowi na temat społeczno-kulturowego wymiaru procesu tworzenia materiałów promocyjnych oraz na temat kultury pracy w dziale marketingu stacji telewizyjnych. Celem artykułu jest rozwijanie wiedzy i zrozumienia na temat promocji telewizyjnej jako dyscypliny zawodowej i praktyki kulturowej w obszarze produkcji mediów. Aby zbadać obszar dotychczas pomijany w rodzimych studiach medioznawczych, autorka artykułu opiera się na wywiadach pogłębionych z pracownikami marketingu w stacjach telewizyjnych, a dokładniej specjalistami ds. public relations. Refleksje praktyków PR w telewizji na temat ich własnej pracy i kon-
\end{abstract}

\begin{abstract}
Promotional campaigns of TV shows often generate a lot of interest and media attention because of their originality and panache. Yet, we know very little about the people who actually plan and execute the promotional activities for television programmes and the institutional context within which they work. This article promotes a reflection on the work culture of practitioners in the marketing departments of Polish TV stations. The aim of the article is to develope knowledge and understanding of TV promotion as a professional discipline and cultural practice in media production. In order to examine the area that has been so far absent from Polish media studies, the article relies on in-depth interviews with TV practitioners, more specifically PR experts responsible for promoting Polish television programming. Reflections of PR practitioners about their own work and their institutional
\end{abstract}

* Uniwersytet Śląski w Katowicach (sylwia.szostak@us.edu.pl); iD https://orcid. org/0000-0001-9119-1874 
tekstu, w jakim się znajdują, dostarczają empirycznych materiałów umożliwiających wyjście poza klasyczne postrzeganie działań promocyjnych, czyli ich analizę jedynie przez pryzmat efektów i skuteczności. Badania etnograficzne sektora produkcji materiałów promocyjnych oferują pełniejszy opis i zrozumienie działań sektora kreatywnego branży telewizyjnej.

Słowa kluczowe: PR, telewizja, seriale, promocja, marketing context provide empirical evidence that allows us to look at the promotion of television programming in ways other than through their effectiveness. The ethnographic research into the marketing departments of Poland's broadcasters offers a fuller understanding of the creative sector and media production in the television industry.

Keywords: PR, television, TV shows, promotion, marketing

\section{Działania promocyjne jako nowy obszar zainteresowań badawczych}

Specjaliści z zakresu marketingu i promocji oraz osoby zainteresowane rynkiem mediów i telewizją często z podziwem, i niekiedy zazdrością, przyglądają się zagranicznym, głównie angloamerykańskim rynkom, gdzie kampanie marketingowe programów telewizyjnych zachwycają rozmachem, pomysłowością, ale przede wszystkim skutecznością w napędzaniu rozgłosu konkretnych pozycji programowych. Wystarczy przytoczyć przykład serialu HBO True Blood czy Gra o tron, których kampanie marketingowe opisywane były w większości amerykańskich czasopism branżowych ${ }^{2}$. Promocja seriali na rynkach angloamerykańskich wzbudza zainteresowanie nie tylko samych specjalistów od reklamy, marketingu, dziennikarzy magazynów branżowych, ale też badaczy naukowych. Badacze $\mathrm{z}$ angloamerykańskiej areny naukowej coraz częściej analizują działania promocyjne oraz strategie marketingowe, które towarzyszą premierom nowych seriali i powrotom na ekrany kolejnych sezonów tych będących już w emisji. Do tego rosnącego zainteresowania badaczy szeroko pojętymi działaniami marketingowymi promującymi programy telewizyjne przyczyniło się kilka czynników. Głównym z nich jest wyłonienie się nowego sektora kreatywnego, specjalizującego się w komunikacji, promocji i brandingu stacji telewizyjnych, a także samych programów, w które inwestuje się nie tylko ogromne pokłady kreatywności, ale i odpowiednio duże budżety. Kampanie promocyjne i strategie marketingowe, coraz częściej niestandardowe, oryginalne i przełamujące dotychczas obowiązujące wzorce, generują niekiedy równie dużo buzzu, co same seriale czy programy

${ }^{2}$ Mam tutaj na myśli magazyny takie jak „Wired”, „Entertainment Weekly”, „Hollywood Reporter". 
telewizyjne, stając się tym samym niezwykle ciekawymi artefaktami kultury audiowizualnej.

Wzrost rangi marketingu programów telewizyjnych i rozwój tego sektora, pod względem liczby zarówno produkowanych materiałów promocyjnych, jak i zatrudnianych specjalistów branżowych, sprawił, że dla badaczy kultury audiowizualnej, promocja produktów telewizyjnych stała się nowym i ekscytującym obszarem zainteresowań badawczych. Drugim czynnikiem, który otworzył akademię na analizę działań promocyjnych w obrębie rynku telewizyjnego, było pojawienie się konkretnych metodologii umożliwiających interwencje badawcze. Ogromny wkład w dziedzinę badań nad działaniami marketingowymi telewizji mieli Paul Grainge i Cathy Johnson. Ci naukowcy z University of Nottingham stali się niejako pionierami badań promocji programów telewizyjnych ${ }^{3}$. Ich praca badawcza pomogła stworzyć nowe sposoby myślenia o roli promocji w telewizji i zmieniła niekiedy lekceważące podejście do marketingu produktów audiowizualnych w dyskursie akademickim i branżowym. Brytyjscy badacze podnieśli status promocji seriali, pokazując ją jako dyscyplinę twórczej i kreatywnej pracy zawodowej. Ich książka z 2015 roku Promotional Screen Industries daje wgląd w społeczność praktyków tworzących materiały promocyjne, które krążą w środowisku medialnym. Do tej do niedawna niewidocznej społeczności zawodowej zaliczają oni pracowników działu marketingu filmowego i telewizyjnego, specjalistów ds. promocji programów, twórców trailerów filmowych i spotów autopromocyjnych, twórców kontentu w agencjach reklamowych i domach mediowych. Pracę tych specjalistów Grainge i Johnson widzą jako odrębny sektor, dla którego proponują nazwę promotional screen industries. Postulują oni, że jeśli chcemy zrozumieć zmiany w kulturze audiowizualnej i branży medialnej, powinniśmy większą wagę przywiązywać do nie tylko kontekstu produkcji samych seriali czy filmów, ale i codziennych praktyk zawodowych i efektów pracy profesjonalistów z dziedziny reklamy, marketingu, brandingu i public relations oraz starać się zrozumieć społeczno-zawodowy kontekst ich funkcjonowania. Do tak zakreślonych celów badawczych wykorzystują wywiady pogłębione ze specjalistami z tej branży (practitioner interviews) i obserwacje terenowe (fieldwork observation) wraz z badaniem struktur instytucjonalnych i analizą materiałów promocyjnych. W tym kontekście opierają się oni na podejściu proponowanym przez Johna Thorntona Caldwella, czyli integrated cultural-industrial approach (Caldwell, 2009a). Takie etnograficzne podejście do badań nad promocją produktów audiowizualnych, które jako przedmiot analizy obiera kulturę pracy w branży promocyjnej, a nie jedynie jej efekty, ma dużo wspólnego z nurtem badań naukowych określanym przez Caldwella jako production studies. Ten nurt otworzył naukę $\mathrm{w}$ obszarach związanych z produkcją audiowizualną na nowe kierunki, oferując analityczne metody badań praktyk zawodowych pra-

\footnotetext{
${ }^{3}$ Inne pozycje, które warto tutaj przytoczyć, to Gray (2010) oraz Wyatt (1994).
} 
cowników branży kreatywnej i ich instytucjonalnym kontekstem. Podobnie jak Caldwell, tak samo Grainge i Johnson oparli swoje badania na pracy terenowej, czyli na wywiadach z przedstawicielami firm oraz z praktykami z branży, koncentrując się na sektorze promocji w Wielkiej Brytanii, Stanach Zjednoczonych i Chinach.

Na gruncie polskim brakuje prac badawczych w nurcie production studies zarówno w obrębie nauki o telewizji, jak i promocji programów telewizyjnych. Nie oznacza to, że marketing programów telewizyjnych jest całkowicie pominięty w polskich badaniach naukowych. Temat ten jest obszernie opracowany przez Annę Jupowicz-Ginalską, jedną z nielicznych badaczek w Polsce, specjalizującą się w tematyce marketingu środków przekazu, która nadała ramy definicyjne i klasyfikujące marketingowi kontentu telewizyjnego, opisując go terminem marketing medialny. Wyjaśniając pojęcie marketingu medialnego, badaczka sięga po dziesiątki przykładów z polskiego rynku mediów, co czyni jej pracę niezwykle wartościową, gdyż osadzoną w naszym lokalnym kontekście. Badaczka analizuje efekty działań marketingowych, kategoryzuje je i objaśnia ich funkcjonowanie. Instytucjonalny wymiar kultury pracy osób zatrudnionych w dziale marketingu jest natomiast poza obszarem jej zainteresowań. Działania promocyjne nie są zatem rozpatrywane w kontekście nurtu badań production studies $^{4}$.

Z uwagi na brak kompleksowego opracowania problemu promocji telewizyjnej w ujęciu proponowanym przez Grainge i Johnson, niniejszy artykuł sprzyja refleksji na temat czynników warunkujących pracę ludzi w dziale marketingu stacji telewizyjnych, ich własne rozumienie instytucjonalnego kontekstu, w którym pracują, codziennie napotykanych wyzwań, jak również stosowanych w praktyce rozwiązań. Jego celem jest rozwijanie wiedzy i zrozumienia na temat promocji telewizyjnej jako dyscypliny zawodowej i praktyki kulturowej w obszarze produkcji mediów. Są to kwestie, których nie sposób zbadać, jeśli działania marketingowe rozpatruje się tylko w kategoriach instytucjonalnych lub bada się jedynie ich efekty. A to właśnie pracownicy działów marketingu i promocji są kreatorami działań promocyjnych, to oni szukają najlepszych sposobów na zapewnienie swoim programom publiczności, wygenerowanie buzzu i utrzymanie statusu quo podziału władzy na rynku telewizyjnym. To właśnie oni w swojej pracy podejmują próbę skompensowania znacznego ryzyka będącego integralną częścią produkcji programów telewizyjnych. To, jakie czynniki mają znaczący wpływ na ich pracę i instytucjonalne ograniczenia ich kreatywności, znajduje odzwierciedlenie w jakości i kształcie materiałów promocyjnych.

${ }^{4}$ Szczególnej uwadze polecam następujące publikacje tej autorki: Jupowicz-Ginalska 2010a; 2010b; 2013; 2015. 
Promocja jest kluczowym elementem obiegu produktów kultury audiowizualnej, to nie ulega wątpliwości. Może zatem czas przyjrzeć się bliżej instytucjonalnym praktykom zawodowym i realiom pracy ludzi, którzy tę promocję tworzą. Intencjonalnie używam tutaj słowa tworzą, ponieważ, podobnie jak Grainge i Johnson, jestem za tym, aby zaliczać pracowników zajmujących się promocją do szeroko rozumianego przemysłu kreatywnego. Nawet Departament Rynku Pracy $\mathrm{w}$ ministerialnym opisie zawodu specjalisty do spraw public relations określa jego pracę jako kreatywną (Okoński, Wójcik, Szpilska, s. 4). Telewizja to miejsce pracy nie tylko personelu kreatywnego, takiego jak scenarzyści, producenci czy aktorzy, ale też twórców kampanii marketingowych, spotów autopromocyjnych, producentów sesji zdjęciowych czy PR-owców odpowiedzialnych za komunikację i relacje z mediami.

Prezentowany artykuł opiera się na wywiadach pogłębionych z pracownikami promocji w produkcji telewizyjnej. Opisują oni ich własne rozumienie kontekstu organizacyjnego i kulturowego, w którym funkcjonują, i który zarazem wpływa na ich działalność. Artykuł opiera się zatem na tym, co Caldwell, w swojej znakomitej książce o kulturze produkcji, nazywa industrial reflexivity (Caldwell, 2008). Tenże dyskurs autorefleksyjny pokazuje, jak przedstawiciele branży marketingu telewizyjnego w Polsce negocjują różne czynniki mające wpływ na ich prace, takie jak struktura organizacyjna branży, zakres obowiązków, ich status w szerszym ujęciu instytucjonalnym oraz relacje w branży, czyli aspekty, które zwyczajowo znajdują się poza obszarem badań medioznawczych w Polsce. Autorefleksyjne narracje praktyków telewizyjnych traktuję podobnie, jak Denise Mann, czyli jako kulturowe artefakty zawierające dowody zawiłego, zazębiającego się systemu silnie skodyfikowanej, dyskursywnej wiedzy (Mann, 2009, s. 104-105). O ile relacje pracowników danego sektora kreatywnego pozwalają lepiej zrozumieć współczesną kulturę produkcyjną i zmiany w branży medialnej, o tyle sam taki materiał nie wystarczy do gruntownej naukowej dyskusji. Materiał pochodzący z rozmów może być postrzegany jako „skażony" dyskurs, jak opisuje to Caldwell (2009b, s. 70) w rozdziale How Producers Theorize, twierdząc, że pracownicy mogą formułować informacje zgodnie z pewnym ustalonym wcześniej zamiarem i interesem, legitymizując tym samym długotrwałe, mocno zakorzenione mity i nie ujawniając faktycznych kulis produkcji. Dlatego też, jak nalega Mann, na badaczu szeroko pojmowanej kultury produkcji spoczywa obowiązek, by na podstawie zachowania i komentarzy przedstawicieli branży wyczuć, czy poddają się oni którymś z tych narzuconych sobie dyscyplinujących działań, czy dokonują autocenzury pewnych informacji, mogących potencjalnie zapewnić badaczowi znaczący wgląd w to, jak faktycznie działa branża (Mann, 2009). Zważywszy na wyzwania stojące przed badaczem materiałów źródłowych tego typu, warunkami powodzenia badań nad kulturą produkcji jest ,współpraca z ekspertami branżowymi i tworzenie 
zespołów złożonych z badaczy posiadających różnorodne kompetencje wynikające zarówno z doświadczeń akademickich, jak i praktycznych" (Wróblewska, 2016, s.14).

Autorka niniejszego tekstu posiada nie tylko akademickie kompetencje pozwalające na podjęcie badań z nurtu production studies, ale też uczestniczyła $\mathrm{w}$ instytucjonalnej organizacji produkcji telewizyjnej, pracując dla stacji TVN od 2015 do 2020 roku. Praktyczne doświadczenie autorki tekstu przekłada się na lepszy wgląd w omawianą tematykę. Posiadane przez autorkę kompetencje, zarówno te praktyczne, jak i akademickie, pozwalają na eksplorację obszaru dotychczas niedostatecznie obecnego w literaturze i na usytuowanie autorefleksyjnej narracji pracowników tego sektora kreatywnego w szerszym kontekście instytucjonalnym.

Badanie środowiska pracy personelu działów marketingu i analiza zakulisowych historii ludzi pracujących w branży umożliwia zbadanie unikatowej kulturowej praktyki produkcji mediów i zaoferowanie czegoś więcej niż zmitologizowane opowieści umieszczane w oficjalnym dyskursie, takim jak materiały prasowe lub artykuły w prasie branżowej. Ten artykuł zatem może stanowić wkład w debatę na temat społeczno-kulturowego wymiaru procesu tworzenia materiałów promocyjnych, uzupełnionego o naukową refleksję. Zdaję sobie sprawę, że artykuł ten przedstawia jedynie wycinek tej rzeczywistości. Ze względu na oczywiste ograniczenia, które wymusza niejako kształt niniejszego artykułu, w pracy tej skupiam się na części branży marketingowej, tej najbliższej i najlepiej mi znanej, a często niedocenianej, której efekty pracy rzadko są w pełni zauważane. Mam tutaj na myśli obszar PR-u telewizyjnego. Zawód PR-owca jest ciekawym przypadkiem do analizy, ponieważ wokół pojęcia narosło w Polsce wiele krzywdzących stereotypów, takich jak chociażby utożsamianie działań z zakresu public relations z czarnym PR-em, który w praktyce ma mało wspólnego z podstawowymi założeniami tej dziedziny $i$ jest jedynie jej wypaczeniem autorstwa politycznych spin doktorów. Naginanie założeń PR-u do celów walki politycznej ma szerokie i szkodliwe społecznie reperkusje dla całej branży PR i jej praktyków. W badaniu zaprezentowanym na konferencji VideoWars by ScreenLovers w 2019 roku, gdzie agencja SW Research sięgnęła po opinie „Zwykłych” Polaków na temat postrzegania rozmaitych profesji, w tym - marketingowych, widoczne jest negatywne postrzeganie zawodu PR-owca w opinii społecznej5. PR-owiec plasuje się na końcu listy wymarzonych zawodów dla dziecka, a także cieszy się najmniejszym zaufaniem społecznym. Przeciętny Polak niechętnie pożyczyłby pieniądze nieznajomej osobie, która przyznałaby się, że pracuje w branży PR.

${ }_{5}^{5}$ Badanie przeprowadzone przez ScreenLovers, IAB Polska oraz SW Research. Całe badanie dostępne jest pod poniższym linkiem: https://screenlovers.pl/rynek-pracy-w-mediach-i-reklamie-badanie-screenlovers-i-iab-polska-appendix-od-sw-research/ [data dostępu: 4.12.2021]. 


\section{Wymarzony zawód dla dziecka}

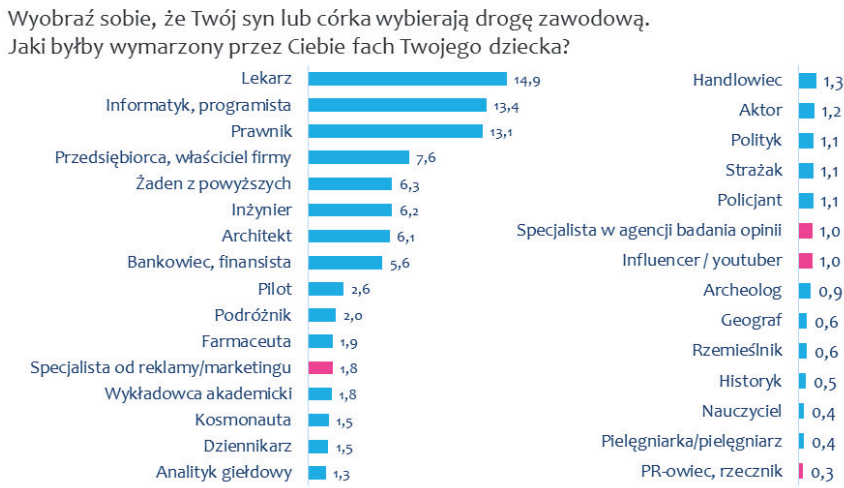

Grafiki umieszczone za zgodą właściciela bloga ScreenLovers.

\section{Komu ludzie pożyczyliby pieniądze?}

Wybór wielokrotny (maksymalnie 3 odpowiedzi)

$$
\begin{array}{rrr|r}
\text { Gdybyś nie znając wcześniej żadnej z tych osób, miał zdecydować której z nich pożyczysz } \\
\text { większą sumę (licząc na ich zwrot), co byś zrobił? Wskaż proszę, przedstawicielom których z } \\
\text { poniższych profesji pożyczyłbyś pieniądze. Zaznacz max. 3 zawody. } \\
\text { Prawnik } & 23,4 & \text { Handlowiec } & 3,3 \\
\text { Lekarz } & 22,7 & \text { Podróźnik } & 3,2 \\
\text { Bankowiec, finansista } & 16,5 & \text { Dziennikarz } & 3,0 \\
\text { Informatyk, programista } & 14,9 & \text { Historyk } & 3,0 \\
\text { Strażak } & 9,9 & \text { Specjalista od reklamy/marketingu } & \text { 3,0 } \\
\text { Architekt } & 9,7 & \text { Polityk } & 2,9 \\
\text { Policjant } & 9,1 & \text { Aktor } & 2,7 \\
\text { Przedsiębiorca, właściciel firmy } & 8,2 & \text { Kosmonauta } & 2,4 \\
\text { Inżynier } & 7,8 & \text { Influencer/youtuber } & 2,4 \\
\text { Farmaceuta } & 7,1 & \text { Archeolog } & 2,3 \\
\text { Pilot } & 5,9 & \text { Geograf } & 1,9 \\
\text { Nauczyciel } & 5,8 & \text { Specjalista w agencji badania opinii } & 1,8 \\
\text { Analityk giełdowy } & 5,3 & \text { PR-owiec, rzecznik } & 1,2
\end{array}
$$

Grafiki umieszczone za zgodą właściciela bloga ScreenLovers.

W obliczu tej społecznej niechęci do zawodu PR-owca płodnym badawczo pytaniem jest: Czy negatywny społecznie stereotyp PR-owca ma wpływ na pracę praktyka tej branży w telewizji? 


\section{Próba definicji roli PR-owca w telewizji}

Public relations jest $\mathrm{w}$ Polsce dziedziną relatywnie młodą; rozwija się dopiero od ok. 30 lat. Pierwsza polska firma zajmująca się public relations powstała w 1990 roku. Była to agencja First Public Relations. Dziś na polskim rynku funkcjonuje ich kilkaset, nie zmienia to jednak faktu, że historia public relations $\mathrm{w}$ Polsce jest bardzo krótka (Czarnowski, 1997). Rokiem przełomowym dla rozwoju polskiego public relations był rok 1994 - to właśnie w tym roku rozpoczęto uruchamianie na poszczególnych uczelniach kierunków o tejże specjalności. Definicja PR-u zależna jest od uwarunkowań środowiska funkcjonowania danej organizacji, tak więc istnieje różnorodność w rozumieniu obowiązków i działań wchodzących w jej zakres. Mimo to można wyodrębnić pewne aspekty, które są kluczowe dla rozumienia public relations jako praktyki zawodowej. W Leksykonie Public Relations zawarto dość obszerną definicję terminu public relations: jako nazwę wszystkich działań zmierzających do osiągnięcia pozytywnych relacji z otoczeniem, jako sposób i styl przekazywania komunikatów i informacji czy organizowania wydarzeń lub jako nazwę dziedziny wiedzy o umiejętnościach zawodowych i sztuce kształtowania wizerunku i marki instytucji, organizacji społecznych i firm gospodarczych w budowaniu reputacji i umacnianiu relacji z otoczeniem. Jerzy Olędzki zauważa, iż światowe organizacje zawodowe definiują public relations jako zarządzanie poprzez komunikację postawami i strategicznymi relacjami pomiędzy organizacją a jej wewnętrznymi i zewnętrznymi akcjonariuszami w celu uzyskania wzajemnych korzyści i większego ładu społecznego (Olędzki, Tworzydło, 2009, s. 141). Podobnie Barbara Rozwadowska określa public relations jako funkcję zarządzania komunikacją między organizacją a jej otoczeniem, gdzie zadaniem public relations jest zarządzanie informacjami dotyczącymi organizacji $\mathrm{w}$ taki sposób, aby pozyskać jak najwięcej osób przychylnie nastawionych (Rozwadowska, 2009, s. 8). W takim ujęciu public relations definiuje się jako długotrwałą, świadomie zaplanowaną działalność informacyjną nastawioną na tworzenie i rozwijanie we własnym interesie przyjaznych relacji z otoczeniem. W literaturze przedmiotu public relations analizuje się również w ramach komunikacji marketingowej i wtedy PR postrzegany jest jako jedno z narzędzi promocji, na równi z reklamą, służące kreowaniu wizerunku i reputacji w otoczeniu wewnętrznym i zewnętrznym przedsiębiorstwa. Już Philip Kotler w swoich pionierskich opracowaniach uwzględniał public relations jako element marketing-mixu, obok działań reklamowych, promocji sprzedaży i innych obszarów promocyjnych.

Przedstawiona definicja PR-u jako zarządzania komunikacją lub jako narzędzia marketingowego jest w takim stopniu elastyczna, że pozwala na różnorodne interpretacje $\mathrm{w}$ praktyce $\mathrm{w}$ zależności od branży, która próbuje ją określić. 
Jeśli chodzi o branżę audiowizualną, działania z zakresu PR w odniesieniu do filmów i programów telewizyjnych mają na celu stworzenie pozytywnego odbioru wśród potencjalnych widzów i użytkowników zachęcającego do obejrzenia danej produkcji. Obowiązki specjalisty PR mogą obejmować różne działania w zależności od tego, czy jest to agencja PR-owa, firma produkcyjna, czy stacja telewizyjna. Można jednak sprowadzić je do kilku podstawowych kompetencji. Według Departamentu Rynku Pracy praca specjalisty do spraw PR polega na: planowaniu działań z zakresu media relations, prowadzeniu profili w mediach społecznościowych, współpracy z agencjami kreatywnymi i domami mediowymi, przygotowywaniu komunikatów prasowych, tworzeniu i aktualizowaniu baz danych mediów, budowaniu i utrzymywaniu stałych relacji z dziennikarzami, analizowaniu danych i opinii pod kątem szans lub zagrożeń dla organizacji, przygotowywaniu materiałów promocyjno-komunikacyjnych, organizowaniu konferencji prasowych i innych wydarzeń prezentujących organizację, organizowaniu wydarzeń dla klientów oraz pracowników (Okoński, Wójcik, Szpilska, 2018, s. 4). Przytoczony opis obowiązków praktyka PR jest tak modydfikowalny, że pozwala na adaptację do konkretnego kontekstu, branży czy grupy zawodowej. Ten aspekt dosyć płynnego i pojemnego zakresu obowiązków stanowiska wybrzmiewa mocno w relacjach pracowników tejże branży. Paulina Sztych zawodowo związana z PR-em od 11 lat, z czego 4 lata opiekowała się PR-owo serialami i programami rozrywkowymi stacji TVN, w następujący sposób opisuje swoje rozumienie instytucjonalnego charakteru pracy eksperta PR w branży telewizyjnej:

Dla mnie największym wyzwaniem, patrząc jakby z lotu ptaka, jest to, że w pracy PR-owca zakres obowiązków jest płynny. Zdefiniowany jest cel i strategia, natomiast środki do niego prowadzące mogę być przeróżne. Co więcej, w każdej branży, firmie PR może być całkowicie odmiennie rozumiany i zupełnie inne kompetencje czy umiejętności mogą być najistotniejsze. $Z$ jednej strony jest to siła i niezwykłość PR-u, który cały czas się zmienia i ewoluuje. $\mathrm{Z}$ drugiej strony jest to branża, która wymaga pewnej elastyczności i otwartości na naukę (Sztych, 2021).

$\mathrm{Z}$ relacji byłego pracownika stacji TVN wyłania się podobny obraz:

W pracy PR-owca dużym wyzwaniem jest fakt, że jest to praca w dużej mierze zadaniowa, ale te zadania trzeba często wyznaczać sobie samemu i samemu pilnować ich wykonania. Z jednej strony jest to dobre, bo pozwala na dużą kreatywność, niezależność i kontrolę nad wykonywaną pracą. W TVN ogromnym plusem jest specjalizacja zadań, czyli jest zespół od organizacji eventów, osobny 
zespół od produkcji materiałów promocyjnych, jest grafik od składu materiałów. W mniejszych firmach takie działania często zrzucane są na jedną, dwie osoby i to właśnie z reguły jest PR-owiec. W TVN, PR-owiec akurat nie musi martwić się o znalezienie miejsca do eventu promocyjnego czy zlecać wydruku potrzebnych materiałów (Anonim, 2021).

Podobnie Róża Adamcio uważa, że praca na stanowisku specjalisty PR w stacji Polsat odbiega znacząco w swoim charakterze od jej wcześniejszych doświadczeń w tym zawodzie w innych instytucjach związanych z produkcją i mediami:

W Polsacie pracuję od półtora roku. W mediach, w PR związanym z mediami od wielu, wielu lat. Zaczynałam od Rodzinki.pl i pracy $\mathrm{z}$ ramienia agencji filmowej w TVP. Potem pracowałam w Akson Studio, czyli firmie produkującej filmy i seriale dla telewizji. Następnie przyszedł czas na radio. Potem pracowałam w Multikinie, no i teraz jestem zatrudniona w Telewizji Polsat. Rola PR-owca w różnych miejscach, gdzie pracowałam, czy to właśnie $\mathrm{w}$ radiu, telewizji, czy kinie, nie zawsze jest taka sama. Definicja PR jest bardzo płynna. W zależności od miejsca pracy PR był specyficzny. Nie mogę powiedzieć, żebym przez te kilkanaście lat mojej kariery w zawodzie ciągle robiła jedno i to samo, mimo że byłam zatrudniona na tym samym stanowisku - specjalisty ds. PR. Ten aspekt jest akurat super, bo miałam okazję nabyć różnych kompetencji. Pracując w Aksonie, musiałam przykładowo też zajmować się też platformami social media, a pracując $\mathrm{w}$ radiu, pełniłam rolę przypominającą rzecznika prasowego. W Multikinie też musiałam wypowiadać się w imieniu firmy, więc to też była trochę inna rola, mimo że formalnie byłam specjalistą PR (Adamcio, 2021).

Z przytoczonych relacji wynika, że działania PR leżące w zakresie obowiązków specjalisty PR w różnych instytucjach związanych z branżą audiowizualną mogą się znacząco od siebie różnić. W związku z tym proponuję, aby do opisu pracy specjalisty PR, którego działania obejmują promocję i komunikację w ramach programów telewizyjnych z ramienia producenta lub stacji telewizyjnej, używać terminu PR telewizyjny. Nie jest to pojęcie, które występuje w literaturze przedmiotu. Jednak uważam, że zakres działań PR w promocji kontentu telewizyjnego zasługuje na odrębną kategorię poznawczą. Taka nazwa $\mathrm{z}$ resztą funkcjonuje w kuluarach branżowych i jest bliska osobom pracującym $\mathrm{w}$ tym zawodzie. 
Pojęcie PR telewizyjny jest mi bliskie i myślę, że dobrze oddaje charakter pracy. Jak się nad tym zastanowię, to faktycznie jest to przydatne sformułowanie, dzięki któremu mogę odróżnić moją obecną pracę w Telewizji Polsat od tego, co wcześniej robiłam. Moje poprzednie doświadczenia zawodowe obejmowały inne obowiązki mimo, że cały czas pracuję w mediach. PR telewizyjny myślę że tak bym określiła to, co teraz robię (Adamcio, 2021).

PR telewizyjny jako odrębna dziedzina działań promocyjnych obejmuje czynności takie, jak przygotowanie i dostarczanie do mediów zestawów informacji na temat programów i stacji (press kits), regularne dosyłanie dziennikarzom informacji wraz z drobnymi upominkami związanymi z konkretnymi propozycjami programowymi, umożliwianie przeprowadzania wywiadów z twórcami i aktorami, organizowanie konferencji oraz innych eventów prasowych, wizyt na planie $\mathrm{z}$ dziennikarzami i fotoreporterami, organizację sesji zdjęciowych. Działania te mają na celu osiągnięcie satysfakcjonujących wyników oglądalności, których oczekuje zarówno producent, jak i nadawca.

Działania z zakresu PR mogą być dobrze realizowane jedynie wtedy, kiedy relacje mediowe prowadzone są efektywnie. Podstawowym zadaniem public relations jest zatem nawiązać, wzmocnić i utrzymywać dialog stacji z docelową grupą odbiorców. Dzieje się to za pomocą pośredników, jakimi są liderzy opinii, dziennikarze, aktorzy. Dzięki nim specjaliści PR mogą w imieniu stacji telewizyjnej przekazywać potencjalnym widzom informacje na temat swojej oferty programowej, licząc na wyróżnienie się na tle konkurencji i wygenerowanie zainteresowania, nieustannie dbając o swój wizerunek. Dlatego też podtrzymywanie relacji branżowych jest dla PR kluczowe. Dla stacji telewizyjnej jednym z najważniejszych aspektów działań PR jest owocna współpraca z tygodnikami telewizyjnymi. Bardzo dużo uwagi poświęca się budowaniu i pielęgnowaniu relacji $\mathrm{z}$ dziennikarzami $\mathrm{z}$ tego segmentu rynku prasowego. $\mathrm{Z}$ punktu widzenia stacji telewizyjnej istotne jest, aby pojawiać się ze swoją ofertą programową również $\mathrm{w}$ mniej sprofilowanych magazynach konsumenckich i prasie codziennej. Takie działania przekładają się na wiarygodność stacji oraz utrzymują jej pozytywny wizerunek oraz zainteresowanie szerszej widowni. Zamieszczona tu prezentacja obowiązków praktyków ds. public relations pracujących w telewizji daje mocne podstawy do tego, aby wyodrębnić ich pracę jako oddzielny segment branży PR, dla którego autorka proponuje nazwę PR telewizyjny. 


\section{Rola i status PR w branży telewizyjnej}

Bezpośrednio w wyniku powstania sektora komercyjnego pod koniec lat 90. XX wieku konkurencja o pozyskanie widzów stała się kluczowa do zabezpieczenia bytu nadawców komercyjnych i równie ważna dla nadawcy publicznego częściowo finansowanego z reklam. Wraz z dojrzewaniem sektora prywatnego w pierwszej dekadzie XXI wieku trzej główni nadawcy naziemni (publiczna TVP i jej dwaj komercyjni konkurenci - TVN i Polsat) zaczęli rywalizować nie tylko z sobą, ale w coraz większym stopniu także z nowo powstałymi tematycznymi kanałami kablowymi i satelitarnymi, takimi jak AXN, FOX, Universal Channel. Sektor telewizji kablowej i satelitarnej, w tym kanały tematyczne przeznaczone głównie dla amerykańskich seriali, stopniowo odciągały polską widownię od nadawców naziemnych. W 2007 roku łączny udział płatnych kanałów telewizyjnych stanowił 20\% udziału w oglądalności osób w wieku 16-49 lat i od tego czasu stale dynamicznie wzrastał: do $24 \%$ w 2008 roku, 29\% w 2009 roku i 32\% w 2010 roku. W 2010 roku. na 38 mln Polaków, którzy korzystali z usług telewizyjnych, 26,6 mln miało dostęp do oferty płatnej telewizji (Szewczyk, 2011). Udział w oglądalności kanałów „Wielkiej Czwórki” (TVN, Polsat, TVP1, TVP2) malał w kolejnych latach z 43\% w 2015 roku do 36\% w 2019 (TeleKabel, 2020). W 2020 roku sumaryczny rynkowy udział wszystkich kanałów filmowo-serialowych wzrósł o 9\% (Wirtualne Media, 2021a), a w pierwszym kwartale 2021 roku ten wzrost wyniósł 15\% (Wirtualne Media, 2021b). W roku 2020 TVN zanotował spadek w oglądalności o 11,4\% do 7,49\%, jeszcze więcej stracił Polsat (o 15,1\% do 8,36\%) (Wirtualne Media, 2021c). Nadawcy naziemni, tacy jak Polsat czy TVN, mają zatem bardzo trudne zadanie, ponieważ nie konkurują jedynie z sobą, ale ze wszystkimi graczami na rynku, tracąc widownię z powodu odpływu widza do stacji tematycznych. Ponadto inne niż linearny sposoby konsumpcji telewizji to dodatkowy czynnik wpływający na spadającą oglądalność głównych stacji. W takiej sytuacji działania marketingowe wydają się bardzo istotne $\mathrm{i}$ to one mogą odegrać decydującą rolę $\mathrm{w}$ sukcesie danego programu lub przeciwnie - jego braku (Eastman, 2000, s. 5).

W dążeniu do przyciągnięcia uwagi widza i zarządzania nią w konkurencyjnym środowisku medialnym, gdzie mamy do czynienia z ograniczoną różnorodnością i nadprodukcją tekstów audiowizualnych oraz wysokim stopniem ryzyka niepowodzenia (Lotz, 2007), promocja jest obecnie ważnym i nieodzownym elementem procesu produkcji i myślenia o programach telewizyjnych. Określenie, które propozycje programowe odnoszą dzisiaj sukces i stają się popularnymi tekstami kulturowymi w porównaniu z tymi, które znikają po kilku odcinkach, często ma dużo więcej wspólnego z samą promocją niż jedynie charakterem programu lub jego walorami estetycznymi czy production value, co dodatkowo podkreśla znaczenie promocji w procesie tworzenia i cyrkulacji produktów au- 
diowizualnych (Baumann, 2007). Działania marketingowe są zatem niezbędne, aby umożliwić sukces nawet najlepszemu serialowi telewizyjnemu (Piątkowski, 2011, s. 220).

W okresie pandemii sytuacja rynkowa uległa znacznemu pogorszeniu. Kryzys wywołany pandemią koronawirusa mocno dotknął działalności w segmencie nadawania i produkcji telewizyjnej, spowodował deteriorację sytuacji finansowej nadawców. W naturalny sposób pandemia zintensyfikowała tendencje, z którymi nadawcy borykali się przed jej wybuchem, przyspieszając długoterminowe procesy, takie jak m.in. migracja widzów od tradycyjnych mediów do platform streamingowych. Również rynek reklamowy bardzo szybko zareagował na zmiany sytuacji makroekonomicznej i na spowolnienie gospodarcze w kraju. Cały polski rynek reklamy i sponsoringu telewizyjnego w drugim kwartale 2020 roku zanotował spadek wartości o 35,4\%. Przychody Telewizji Polsat z reklam i sponsoringu zmniejszyły się w roku 2020 o 34,5\% (Wirtualne Media, 2020a). Polsat i TVN zareagowały na sytuację rynkową redukcją średniej ceny cennikowej, a i tak firmy mniej chętnie wydawały pieniądze na reklamę telewizyjną. Mimo szybkiej reakcji na sytuację gospodarczą w kraju oba kanały komercyjne w okresie pandemii sprzedały mniej reklam, a dodatkowo sprzedany czas reklamowy miał niższą cennikową wartość niż w analogicznym okresie w latach wcześniejszych (Wirtualne Media, 2020b). Dodatkowo TVN czy Polsat są w trudniejszej sytuacji niż TVP, gdyż nie mogą liczyć na wsparcie państwa. Obecnie media publiczne otrzymują z budżetu ok. 2 mld zł. Taka dotacja będzie przekazywana rok w rok przez najbliższe 5 lat. Jeśli spojrzeć dzisiaj na rynek, to poza telewizją do niedawna publiczną, która otrzymuje potężną „finansową kroplówkę” od państwa, wszyscy nadawcy konfrontują się z dużymi kłopotami budżetowymi, zagrażającymi ich dotychczasowej strukturze i działaniu (Wirtualne Media, 2021d).

Ostatnie redukcje personalne w TVN Grupa Discovery to konsekwencja pandemicznego spowolnienia na rynku reklamowym, które zmusza nadawców naziemnych do redukcji kosztów operacyjnych. TVN24 co prawda notuje rekordową oglądalność, ale nie zrekompensuje to spadku wyników głównego kanału TVN (Wirtualne Media, 2021d). Widoczne oszczędności w TVN Grupie Discovery zaczęły się jesienią 2020 roku od znaczącego zmniejszenia zespołu zarządzającego, który od przejęcia Grupy TVN przez Discovery liczył nawet kilkanaście osób. Z końcem października 2020 roku z zarządem spółki rozstał się szef marketing), a w połowie lutego 2021 roku z firmy odszedł dyrektor komunikacji korporacyjnej. Po wielu latach pracy z TVN pożegnali się dyrektor działu promocji oraz szef sekcji patronatów. W wyniku redukcji w TVN Grupa Discovery od stycznia $2021 \mathrm{z}$ departamentem marketingu rozstało się ponad 10 osób (Wirtualne Media 2021d). Redukcje etatów w TVN to nie jedyny sposób na zmniejszenie kosztów operacyjnych. Oszczędności spowodowały również ograniczania budżetów marketingowych. Marketing jest często postrzegany 
jako wydatek uznaniowy, a zatem jest jednym z pierwszych obszarów, w których firmy gotowe są wprowadzić cięcia.

W sytuacji intensywnej konkurencji na rynku marketing danego programu czy serialu telewizyjnego zwiększa jego szansę na sukces. W momencie, kiedy zasoby działu marketingu są uszczuplane, w naturalny sposób ciężar odpowiedzialności za działania promocyjne spada na zespół PR. Aleksandra Skwarek, Head of PR Constantin Entertainment Polska, twierdzi, że:

Stacje coraz częściej oszczędzają na kampaniach marketingowych, na reklamie, outdoorze, sesjach wizerunkowych. Nawet jeśli autopromocja na antenie jest silna, to brakuje przebicia na zewnątrz. Wtedy zostaje tylko PR oparty na działaniach bezkosztowych. Gra jest warta świeczki. Dobre wyniki pozwalają nam walczyć o kolejne sezony, a to dla produkcji jest najważniejsze, aby mieć kontynuację danego programu. Każdy kolejny sezon jest łatwiejszy do zrealizowania pod kątem budżetowym, więc dla producenta najlepszym rozwiązaniem jest kontynuować dany tytuł, a nie ciągle inwestować w nowości. Dlatego tak ważne jest odpowiednie przygotowanie PR-owe (Skwarek, 2021).

W sytuacji znaczących redukcji budżetów na marketing i płatne działania promocyjne dramatycznie rośnie wartość działań w zakresie public relations, które prowadzone są bez dodatkowych nakładów finansowych ze strony producenta lub nadawcy. Pracodawca nie ponosi żadnych kosztów oprócz tych związanych z zatrudnieniem pracowników na stanowisku specjalistów PR. Specjaliści PR w stacjach telewizyjnych nie dysponując budżetem, korzystają z zasobów niematerialnych i własnych zasobów intelektualnych. Wśród nich wyróżnić można m.in. zasoby organizacyjne, czyli system zarządzania swoją pracą, kulturę organizacyjną, wiedzę, własność intelektualną oraz relacje z otoczeniem i własną reputację (Pluszyńska, 2015, s. 46). Gdyby spróbować przyjrzeć się poszczególnym formom działań z zakresu PR, można by zauważyć, że wszystkie mają charakter bezkosztowy, gdyż oparte są na kontaktach bezpośrednich wypracowanych indywidualnie w dłuższej perspektywie przez praktyka PR. Kontakt mailowy, stały kontakt telefoniczny, nieformalne rozmowy, różnego typu imprezy branżowe (uroczyste premiery, konferencje prasowe, pokazy dla dziennikarzy) czy prezentacje aktualnej i przyszłej oferty odgrywają kluczową rolę w działaniach PR programów telewizyjnych i stanowią jedyne kanały dotarcia służące przekonaniu dziennikarzy i liderów opinii takich, jak krytycy filmowi i telewizyjni, lokalni trendsetterzy z poszczególnych sektorów rynku mediów do współpracy z danym nadawcą czy producentem. Utrzymywane przez wiele lat relacje międzyludzkie i kontakty branżowe są kluczowymi narzędziami PRowymi i wpisują się współcześnie w zakres działań public relations. To dzięki 
nim specjalista PR jest w stanie wygenerować wartość dla nadawcy, zapewniając publikacje na temat aktualnej oferty programowej w prasie i w Internecie bez ponoszenia przez niego kosztów.

Docenienie działań public relations i dostrzeżenie wartości, jaką mogą wygenerować dla stacji telewizyjnej specjaliści PR, nie powinno być motywowane jedynie brakiem budżetów marketingowych na płatne formy promocji, ale przede wszystkim mającą obiektywne uzasadnienie słabością marketingu i reklamy. Konsumenci stają się o wiele mniej podatni nawet na coraz bardziej wymyślne działania marketingowe, a skuteczność przekazu reklamowego maleje czasami wprost proporcjonalnie do wzrostu jej kosztów. W zasadzie, gdyby nie ugruntowane w świadomości decydentów z rad nadzorczych i zarządów wielkich korporacji przekonanie, że określony procent należy bezwzględnie wydać na marketing i reklamę, to ich znaczenie już dzisiaj byłoby zdecydowanie mniejsze. Niejednokrotnie głównym beneficjentem wydatków na marketing i reklamę firm są agencje marketingowe i reklamowe (Ries, Ries, 2004). Działania public relations z kolei coraz częściej zalicza się do najpotężniejszych i uznawanych przez odbiorców za najbardziej autentyczne i wiarygodne kanały komunikacji. Praktycy i teoretycy marketingu dość często uznają public relations za dziedzinę, która będzie przynosiła lepsze rezultaty niż reklama, ponieważ, jak twierdzą, rynek został przesycony tradycyjną reklamą (Bobińska, 2000, s.192). Zatem, działania takie, jak publikacje prasowe lub newsy na portalach internetowych, są o wiele bardziej wiarygodne niż płatna reklama czy jakakolwiek inna płatna forma marketingowa. Jeśli zaś chodzi konkretnie o telewizję, to w tym sektorze działania public relations są zaraz po autopromocji najbardziej efektywnym sposobem komunikacji między stacją telewizyjną a jej widownią (Baumann, 2007, s. 57-58).

\section{Status zawodu specjalisty PR w autorefleksyjnej narracji praktyków branżowych}

Wydawać by się mogło, że działania prowadzone przez specjalistów PR będą coraz bardziej cenione $\mathrm{w}$ branży telewizyjnej, która jest rynkiem nie tylko bardzo kompetytywnym, ale też mocno dotkniętym przez pandemię koronawirusa. Specjaliści public relations pracujący w telewizji w swojej autorefleksyjnej narracji pokazują jednak, że ich praca nie cieszy się szacunkiem współpracowników. Wręcz przeciwnie, mówią oni zgodnym głosem, że w swoich codziennych działaniach konfrontują się z licznymi instytucjonalnymi trudnościami, które utrudniają im pracę oraz stanowią poważne ograniczenie dla ich kreatywności. Róża Adamcio z Telewizji Polsat w następujący spo- 
sób opisuje instytucjonalne przeszkody, które napotyka w swojej działalności zawodowej:

Mam poczucie, że nie jestem traktowana poważnie i że moja praca nie jest traktowana poważnie. To troszeczkę się poprawiło na przestrzeni ostatnich lat. Dziesięć lat temu, na początku mojej kariery w public relations to był dramat. Panowała wtedy opinia w branży, że PR-owiec to jakaś młoda dziewczyna, która tylko przychodzi i przeszkadza. Spotkałam się z taką opinią osobiście i nie raz. Uważam to za pewnego rodzaju uprzedzenie do tego zawodu, ale też brak szacunku do roli PR-owca. Wielokrotnie spotykałam się z opinią, że PR jest niepotrzebny; że ja tylko mnożę koszty, a w żaden sposób nie przyczyniam się do generowania zysku dla firmy. Panuje również takie przekonanie w branży medialnej, że każdy może robić PR. Co to za problem napisać informację prasową i wysłać do dziennikarzy. Często odczuwam niechęć wobec mojej roli. Przykładowo, dzwonię z jakimś tematem do innych działów mojej firmy, aby otrzymać potrzebne mi materiały, a jestem traktowana jakbym przeszkadzała. Nie ma w Polsacie zrozumienia, że ja jako PR-owiec też jestem ważnym elementem całej tej układanki (Adamcio, 2021).

Karolina Kurek, specjalistka PR z doświadczeniem agencyjnym, zawodowo związana z TVN 6 lat, obecnie Brand Manager w Kino Polska, doświadczyła analogicznych wyzwań:

Spotkałam się osobiście z różnymi podejściami do PR. Jednym z popularniejszych jest przeświadczenie, że każdy zna się na PR, co moim zdaniem wpływa na umniejszanie roli osób, które zajmują się PR-em. W przypadku powodzenia programu telewizyjnego, serialu czy filmu sukces ma wielu ojców, a porażka jest zazwyczaj przypisywana niewystarczającym działaniom komunikacyjnym, co moim zdaniem dobrze ilustruje, jaki jest szacunek do pracy PR-owca. Widzę, że producenci coraz częściej dostrzegają, że osoby z marketingu czy PR ,grają do tej samej bramki”, czyli że sukces danej produkcji jest ich wspólnym celem. Producenci coraz częściej pomagają PR-owcom, współpracują, nie traktują ich wizyty na planie jako zła koniecznego. Myślę, że naszej pracy pomogłoby traktowanie PR-owców jako specjalistów w swoim fachu i zaufanie do naszej pracy (Kurek, 2021).

Były pracownik stacji TVN w podobnym tonie opisuje swoje doświadczenia jako praktyka PR-u telewizyjnego: 
Praca w zawodzie PR-owca nie jest według mnie społecznie postrzegana jako prestiżowa. Bywa to dosyć niewdzięcznym zajęciem. Trzeba wychodzić z inicjatywą, proponować dużo pomysłów na publikacje, niekiedy o nie aktywnie zabiegać. Bywa, że czasem jesteśmy traktowani jak chłopiec na posyłki. W sytuacjach kryzysowych to właśnie PR-owiec musi gasić przysłowiowe pożary. Może to oznaczać zszycie pękniętej sukienki na evencie, znalezienie miejsca parkingowego dla gwiazdy, zrobienie kawy, przyniesienie szklanki wody, a czasem nawet zażegnanie konfliktu lub pacyfikację czyjejś agresji werbalnej. Taki zakres nieformalnych obowiązków wynika $\mathrm{z}$ faktu, że PR-owiec operuje $\mathrm{w}$ dość trudnym kontekście instytucjonalnym. Jest pracownikiem korporacyjnych struktur, jego szefem jest więc dyrektor marketingu lub bezpośredni menadżer, ale też musi zadowolić potrzeby i oczekiwania producentów. Jest też takie poczucie, że aktorzy czy gwiazdy programów rozrywkowych muszą również być zadowoleni z pracy PR-owca. Jeśli chodzi o dziennikarzy, to w obecnym klimacie to raczej PR-owiec musi zabiegać o względy i uwagę dziennikarzy. PR-owiec jest zatem osobą raczej podrzędną względem osób, z którymi współpracuje (Anonim, 2021).

Kotler, uznany na całym świecie autorytet $\mathrm{w}$ dziedzinie marketingu, uważa public relations za dodatek do działań marketingowych prowadzonych $\mathrm{w}$ organizacji. Traktuje on PR ,jako przybrane dziecko marketingu”, swego rodzaju uzupełnienie poważniejszych działań promocyjnych (Cenker, 2000, s. 4). Według niego marketing jest pojęciem nadrzędnym, dużo bardziej istotnym z perspektywy działań promocyjnych. W przedstawionych relacjach znajdujemy potwierdzenie, że takie podejście nadal jest aktualne: współpracownicy często widzą $\mathrm{w}$ public relations podrzędną funkcję marketingową. W rezultacie praca $\mathrm{w}$ sferze public relations wywołuje nieuzasadniony kompleks nawet u tych, którzy mają w tej dziedzinie znaczące osiągnięcia.

Istotny wydaje się aspekt, że PR w potocznym postrzeganiu sprowadzany jest do tak trywialnych działań, jak „wysyłka informacji prasowych”, działań, które faktycznie mógłby wykonywać każdy. Na porządku dziennym jest - jak się wydaje - dostrzeganie jedynie części instrumentów PR, podczas gdy wiele narzędzi PR-owych nie jest powszechnie znanych. Owszem, PR zajmuje się zarządzaniem informacjami, obejmuje jednak dużo więcej niż tylko redagowanie i kolportowanie notatek prasowych. Są to bowiem środki techniczne, jedne spośród wielu stosowanych przez PR. Domeną PR-u jest odpowiednie administrowanie informacjami - czynność, którą cechuje duża precyzja. Panowanie nad wieloma strumieniami wychodzących i napływających informacji wymaga m.in. zdolności precyzyjnego działania w tym obszarze, nie mówiąc już o nie- 
zbędnej umiejętności szerokiego oglądu aktualnej sytuacji przez pryzmat sytuacji pożądanej w dłuższej perspektywie.

Bardzo mylne jest myślenie, że efekty pracy komórki public relations, pracującej na rzecz wizerunku organizacji, polegają jedynie na wysyłce i publikacji materiałów prasowych. Sama wysyłka nie gwarantuje publikacji tychże materiałów. Takie przeświadczenie wynika z niezrozumienia oczywistego faktu, że reklama i PR to dwie różniące się zasadniczo dziedziny. Wydaje się to specjalistom innych dziedzin trudne do zrozumienia. PR i marketing to dwie odmienne sfery zarządzania treścią. Działania PR różnią się tym od reklamy, iż reklamodawca bezpośrednio płaci za ekspozycję przekazu w danym nośniku, kontroluje, w jakim nośniku się on pojawi i jak często będzie emitowany, oraz wie dokładnie, jak będzie wyglądał ten przekaz. Natomiast PR nie ma całkowitej kontroli nad dalszym przekazem komunikatów przesłanych do mediów, nie ma też wpływu na ich skuteczność (Domański, Kowalski, 2000, s. 263-268). Nie oznacza to natomiast, że w przypadku kontaktów z mediami niewielka jest kontrola nad tym, co, komu i kiedy jest przekazywane. PR stosuje po prostu bardziej subtelne niż reklama techniki wpływania na obraz organizacji (i jej produktów) w mediach. $\mathrm{Z}$ tego m.in. wynika konieczność prowadzenia działań PR w długiej perspektywie czasowej oraz konieczność zdobywania wiarygodności w środowisku dziennikarskim. Niezrozumienie dynamiki działań PR sprawia, że błędnie traktuje się je jako działania względnie doraźne, mające na celu uzyskanie maksymalnego efektu w możliwie krótkim czasie. Dlatego też nie jest możliwe uzyskanie efektów PR-owych jedynie poprzez wysyłkę materiałów prasowych. Techniki budowania własnego lobby w tym środowisku, tworzenie nieformalnych kręgów kontaktów zawodowych, różnego rodzaju techniki wzmacniania zainteresowania dziennikarzy daną stacją telewizyjną i jej produktami to właściwa, i w sumie jedyna skuteczna, droga do tworzenia warunków efektywnego komunikowania się z mediami, a więc i z widownią. Trzeba również pamiętać, że miarą sukcesów praktyka PR jest nie tylko to, co ukazało się $\mathrm{w}$ mass mediach, ale również - a w niektórych przypadkach przede wszystkim - to, co się w mediach nie ukazało, choć ukazać się mogło. Niezbędnymi warunkami do osiągnięcia sukcesu w kontaktach z mediami jest również znajomość specyfiki zawodu dziennikarza i pracy poszczególnych redakcji oraz dobre rozumienie aktualnej dynamiki rynku prasowego. Public relations jest dziedziną wiedzy, a nawet swego rodzaju sztuką prowadzenia określonych działań, czego zdają się nie wiedzieć pracownicy bez kompetencji PR-owych.

Tutaj warto również wspomnieć, że przy tak dobrze prosperującej produkcji dla telewizji mamy obecnie na rynku do czynienia z bardzo dużą konkurencją nie tylko o widza, ale także o uwagę dziennikarza. Publikację materiałów prasowych o danej pozycji programowej w tygodnikach telewizyjnych utrudnia ogromna liczba dostępnych programów. $\mathrm{Z}$ kolei inne segmenty rynku prasowe- 
go niekoniecznie mogą być zainteresowane współpracą ze względu na ich inny niż telewizyjny profil. Do zadań specjalisty PR należy zatem pielęgnowanie kontaktów, dzięki którym przebicie się z informacją i zaistnienie we wszystkich segmentach prasy będzie możliwe. Budowanie takich relacji z mediami, a także zarządzanie nimi w efektywny sposób możliwe jest dzięki utrwalaniu i wzmacnianiu relacji z dziennikarzami. Sami PR-owcy doskonale wiedzą, że dobrze realizowany PR opiera się na dobrej ocenie w środowisku zawodowym, na wiarygodnych referencjach, na umiejętności dbania o relacje międzyludzkie, komunikacji interpersonalnej, empatii i profesjonalizmie w działaniu. Dodatkowo, PR-owiec musi doskonale znać potrzeby rynku mediów i mieć kreatywne propozycje na ich realizację. Dzięki temu już na etapie przygotowywania programu może wprowadzić konkretne, atrakcyjne dla dziennikarzy działania, takie jak spotkania prasowe na planie czy udział fotosisty w wybranych dniach zdjęciowych. Jednocześnie praktyk ds. public relations musi potrafić zrozumieć strategię marketingową stacji oraz potrzeby produkcji.

Trudności z przebiciem się do prasy są również następstwem wyzwań, z jakimi zmaga się w ostatnich latach cała branża wydawnicza. Spadek sprzedaży drukowanych czasopism zmusza niektóre wydawnictwa do zerwania z tradycyjną częścią biznesu. Przykładowo, jesienią 2018 roku wydawca Marquard Media wycofał z rynku magazyn ,Shape”. W grudniu 2019 roku zniknęły z rynku prasowego takie tytuły jak „CKM”, „Cosmopolitan”, „Esquire”, „Harper’s Bazaar”, „Joy” i „Playboy”. W grudniu 2020 roku wydawnictwo Edipresse wycofało z rynku „Flesz. Gwiazdy \& Styl”, po czterdziestoprocentowym spadku sprzedaży. Najważniejsze dwutygodniki z segmentu people należące do Edipresse notują znaczące spadki: „Party. Życie Gwiazd” w listopadzie 2020 roku zanotował spadek sprzedaży aż 30\% względem analogicznego okresu roku wcześniejszego. „Viva” zanotowała w tym samym okresie najmniejszy, ale jednak znaczący spadek o 20\%. Wynik magazynu "Show” (Wydawnictwo Bauer) w listopadzie 2020 roku zmalał o 26\%. „Gala” (Burda International Polska) zanotowała spadek o 33\% (Wirtualne Media, 2021e). Podobny trend widoczny jest w segmencie tygodników telewizyjnych. Tytuły takie jak „To \& Owo”, „Tele Świat”, „TV 14”, „Telemax”, wszystkie zanotowały spadek sprzedaży na poziomie między 5 a $10 \%$. Program TV zanotował największy spadek sprzedaży w tamtym okresie, o aż 11,4\%. „Tele-Tydzień” (Wydawnictwo Bauer), lider sprzedaży w tym segmencie, zanotował w 2019 roku spadek względem roku poprzedniego o 7\%. W efekcie tak znaczących spadków sprzedaży wydawnictwa redukują koszty operacyjne i przenoszą działalność do sektora online, powodując dramatyczny spadek liczby zatrudnionych w redakcjach dziennikarzy. Mniejsza liczba tytułów prasowych oraz mniejsza liczba dziennikarzy powoduje, że coraz trudniej jest przebić się z daną informacją prasową, gdyż po pierwsze, istnieje mniej platform do ich ulokowania, ale też dziennikarze nie są w stanie opracować wszystkich przysyłanych do nich informacji. Ze względu na finansowe trudności branży 
prasowej i mediów ogólnie dziennikarze są mniej skłonni współpracować ze stacjami telewizyjnymi w ramach współpracy barterowej, wybierając płatne formy współpracy, takie jak artykuły sponsorowane lub działania P\&A (print and advertising). Ola Skwarek z Constantin Entertainment odczuwa te zmiany w swoich relacjach z dziennikarzami:

Dziennikarze już inaczej współpracują z PR-owcami niż jeszcze kilka lat temu. Bartery, bezkosztowe publikacje, patronaty redakcyjne, newsy na wyłączność - zdobycie tego jest coraz trudniejsze. Dziennikarze mocno selekcjonują kontent i niestety polegają coraz częściej na płatnych współpracach. PR-owiec musi być elastyczny i dzięki wypracowanym relacjom i kreatywności proponować rozwiązania przynoszące korzyści obu stronom - stacji czy producentowi i jednocześnie redakcji (Skwarek, 2021).

Ten brak szacunku, który odczuwają specjaliści branży PR, możne wynikać z faktu, iż PR-owcy czują, że ich współpracownicy nie rozumieją dokładnie, czym w ogóle zajmuje się PR.

Pracownicy innych działów marketingu mają raczej mgliste wyobrażenie o tym, czym zajmuje się PR. Natomiast wszystkie dalsze działy nie rozumieją specyfiki tej pracy, więc mylenie na przykład PR-u z marketingiem płatnym jest na porządku dziennym. Dostaję często zapytania o reklamy outdoorowe lub zwiastuny antenowe. Nawet zdarzyło mi się usłyszeć takie pytania od produkcji. Jest to poniekąd zrozumiałe, bo oni są dosyć daleko strukturalnie od działów komunikacyjnych, więc nie mają w pionie produkcyjnym znajomości specyfiki tej pracy. W rezultacie bardzo często dochodzi do nieporozumień i nawet konfliktów, które biorą się z nierealnych oczekiwań wobec PR-u, wynikających z niezrozumienia, czym są działania z zakresu public relations. Gdyby zadać producentom lub pracownikom innych działów pytanie, co taki PR-owiec robi i co on realnie może wypracować dla programu, to myślę, że mało kto umiałby odpowiedzieć, nie myląc przy tym właśnie marketingu płatnego czy patronatów. To się zlewa ludziom w jedno. Myślę, że również tak szerzej społecznie, praca PR-owca nie jest dobrze zrozumiana. Ludzie nie wiedzą dokładnie czym jest PR i jakie są obowiązki PR-owca. Ja do dziś nie byłam w stanie wytłumaczyć rodzinie, co to dokładnie znaczy i czym się zajmuję. Ma to związek z tym, że efektów pracy PR-owca nie widać $i$ trudno je zmierzyć. Ja też czasami patrzę na siebie i swoje koleżanki podczas eventów i myślę, że z zewnątrz to może wyglądać, że my tylko biegamy w jakimś amoku. W konsekwencji 
PR jest traktowany trochę po macoszemu, a PR-owcy spotykają się z mało entuzjastycznym przyjęciem (Sztych, 2021).

Jeżeli poczynione obserwacje dotyczące mylnego zrównania funkcji komórek public relations ze świadczeniem usług na rzecz marketingu są reprezentatywne i jest to rzeczywiście zjawisko powszechne, należałoby się zastanowić nad przyczynami takiego stanu rzeczy. Następuje tutaj po raz kolejny pomieszanie warsztatu i etyki zawodowej dwóch odmiennych dziedzin. Można zaryzykować stwierdzenie, że koncepcje przyjęte przez wspomnianego już Kotlera przyczyniły się do tego, że nadal jest wiele osób, które postrzegają PR jako element działań marketingowych, zawężając tym samym definicję i upraszczając cały proces rozumienia public relations. Ujmując problem definicyjnie, PR nie jest reklamą. Takie pojmowanie PR wydaje się dość reprezentatywne dla sposobu rozumowania wielu z tych, którzy umieszczają public relations w obszarze marketingu. Techniki marketingowe różnią się ogromnie od instrumentarium stosowanego w PR. Marketing, reklama i public relations mają wiele elementów wspólnych, ale nie tłumaczy to prób uprawiania kłusownictwa przez jedną $z$ tych dziedzin na terenie innej. Duża firma zazwyczaj ma działy zarówno marketingu, jak i public relations. PR jest elementem zarządzania informacją, zatem można go wykorzystywać spójnie z szeroko zakrojonymi działaniami marketingowymi, które prowadzą do celów założonych przez właścicieli podmiotów rynkowych. Ich funkcje będą się czasem stykały, ale w pewnych sytuacjach będą zupełnie oddzielne. Nie będąc specjalistami PR, pracownicy branży telewizyjnej mają wyraźne problemy z nazwaniem poszczególnych narzędzi marketingowych oraz PR-owych. Współpracownicy niestety rzadko stawiają pytania, które pomogłyby rozwiać definicyjne różnice pomiędzy marketingiem a PR-em. Często nie rozumieją też istoty problemu. PR często definiuje się zatem jako domenę marketingu. Traktowanie public relations jako części składowej marketingu mocno ugruntowało się na polskim rynku. Takie podejście ma swoje obiektywne uzasadnienie. W Polsce bowiem najpierw pojawił się marketing, a dopiero później - zarówno w programach studiów, jak i w praktyce życia gospodarczego - profesjonalny public relations. Powodem niezrozumienia działań public relations może być jednoczesny rozwój tego rynku i rynku reklamowego, przez co stało się prawie niemożliwe rozdzielenie w umysłach konsumentów tych dwóch obszarów (Stopczyńska, 2001). Stąd też chaos w widzeniu public relations przez pracowników wielu firm.

Co więcej, działania z zakresu public relations z założenia powinny być tak subtelne, aby konsument nie odczuwał ich celowej obecności (Piątkowski, 2011). Dlatego też dyscyplina PR jest mniej konkretna niż bardziej mierzalne narzędzia marketingowe. Oczywiście, istnieją narzędzia pomiarowe do głębszych analiz działań z zakresu public relations, takie jak chociażby sondaże, pomiary porównawcze przed i po oraz w trakcie kampanii PR oraz metody ilościowe 
i ekwiwalent reklamowy. Jednak stacje telewizyjne nie udostępniają swoim szeregowym pracownikom żadnych innych narzędzi pomiarowych niż monitoring mediów oraz pomiar ekwiwalentu reklamowego. Dodatkowo trudno też dowieść, jaki udział w sukcesie serialu telewizyjnego mają działania z zakresu PR. Eksperci podkreślają, że sukces programu telewizyjnego to wypadkowa wielu czynników, takich jak sam pomysł, kreatywność twórców, warsztat i budżet realizatorów, wizerunek i popularność stacji telewizyjnej, ale także działania marketingowe, w tym te o charakterze promocyjnym (Eastman et al., 2006, s. 25). Joanna Karawaj $\mathrm{z}$ agencji mediowej Wavemaker $\mathrm{w}$ następujący sposób wypowiada się o mierzalności efektów działań PR w kontekście telewizji:

Dziś działania komunikacyjne musza być mierzalne. I nie mam na myśli tylko analizy oglądalności czy zasięgu kampanii reklamowej. Dziś marki chcą i dzięki zaawansowanym narzędziom mogą wiedzieć, jak poszczególne aktywności mediowe kontrybuują w procesie zakupowym, który element media planu odpowiada za sprzedaż. Jak zestawimy to z możliwościami pomiaru działań PR, gdzie poza liczbą publikacji czy wskazań lub wejść na stronę www niewiele więcej się mierzy, widać przepaść i to może być jedną z przyczyn (albo i rezultatów) trudnej sytuacji PR-u w polskim krajobrazie mediowym. To dlatego public relations jest tym obszarem, który trudno jest precyzyjnie zdefiniować z punktu widzenia marketingu (Karawaj, 2021).

Ze względu na charakter działań PR-owych, o którym mówi Karawaj, dyscyplina PR może być trudna do zrozumienia, gdyż nie widać jej mierzalnych efektów, trudno ją opisać i zrozumieć jej realną wartość ${ }^{6}$. Ta efemeryczna właściwość PR-u sprawia, że bardzo łatwo i niekiedy chętnie zrzuca się winę za brak sukcesu komercyjnego danego programu właśnie na działania komunikacyjne. Jednak dobra znajomość dynamiki działań public relations podpowiada, że reklamą płatną czy działaniami PR można przyciągnąć widownię na trzy pierwsze odcinki, później kontent telewizyjny musi obronić się sam. Mamy tutaj do czynienia zatem z takim mechanizmem, wedle którego na pewnym etapie o osiągnięciu sukcesu decyduje już tylko sam produkt i jego jakość.

${ }^{6} \mathrm{O}$ aspekcie mierzalności można przeczytać w następujących źródłach: Weiner (2006 oraz Smith (2021). Na gruncie polskim o mierzalności działań PR pisze dr Anna Miotk z Katedry Komunikacji Społecznej i Public Relations na Wydziale Dziennikarstwa, Informacji i Bibliologii Uniwersytetu Warszawskiego. 


\section{Komunikacja w strukturach instytucjonalnych}

Piotr Bielawski, znany polski specjalista w dziedzinie public relations, używa ciekawej definicji PR-u i brzmi ona następująco: jest to umiejętność przekazania właściwym osobom właściwej informacji we właściwym momencie, w celu wywołania pożądanego efektu (Bielawski, 2006). Warto w tym miejscu podkreślić, jak wiele zależy od specjalisty PR i jego umiejętności odbierania informacji od właściwych osób, we właściwym czasie, by uzyskać możliwość wywołania pożądanego efektu. Rozrost stacji telewizyjnych powoduje, że strukturalnie przekształcają się one w korporacje składające się z wysoce wyspecjalizowanych działów. Widać to dobrze na przykładzie Polsatu i stacji TVN, gdzie w skład działu marketingu wchodzą także zespół PR, zespół promocji i zespół produkcji eventów. Produkcją autopromocyjnych materiałów antenowych zajmuje się osobny dział, mediami społecznościowymi zajmuje się dział promocji online, a promocją Playera jeszcze inny. Problemem w tak rozbudowanej strukturze okazuje się komunikacja i przepływ informacji między działami. W praktyce oznacza to, że mamy do czynienia z bardzo wąskimi specjalizacjami, często bez kontaktu z realiami produkcyjnymi, kosztem wzajemnej współpracy i komunikacji, mimo że wszyscy działają dla dobra tego samego programu. Według Adamcio takie strukturalne wyzwania bardzo utrudniają jej pracę:

Komunikacja w strukturze Polsatu jest wyzwaniem. Trudno mi czasami wyegzekwować informacje, które potrzebne mi są do wykonywania moich obowiązków. Mam zająć się danym projektem, a ciężko mi się o pewne materiały doprosić. Zdarzyło się kiedyś, że w ogóle nie dostałam do promocji jednego programu zdjęć. Nie ma zrozumienia dla faktu, że nie mam narzędzi do wykonywania swojej pracy. Mam promować program, ale nawet nie wiem czasami, kiedy będzie jego premiera. Mamy dział social mediów, mamy marketing, mamy autopromocję, jest PR, no i tu nie ma za bardzo dialogu. Każdy gra do osobnej bramki, mimo że powinniśmy działać w teamie. Kiedy borykasz się z brakiem podstawowych narzędzi i materiałów, powoduje to frustrację. Potrzebuję obejrzeć odcinek, żeby móc wyciągnąć z niego fajne rzeczy i zaplanować promocję, a ja czasem proszę o ten odcinek i nikt nie jest w stanie mi pomóc. Jeśli nie dostanę zdjęć to sama muszę robić screeny. A screen, rzecz jasna, jest bardzo słabej jakości, i nie będzie z tego publikacji w prasie drukowanej. Podstawą jest dla mnie informacja i dobre zdjęcie (Adamcio, 2021).

Warto tutaj przypomnieć, że liczba działów firmy, z którymi powinien współpracować PR, jest bardzo duża. Komunikacja PR-owa powinna być reali- 
zowana w ścisłej współpracy z pionem produkcyjnym, ze scenarzystami, z departamentem odpowiedzialnym za promocję online, jeśli firma taki posiada. PR musi widzieć całą organizację i to $\mathrm{W}$ dalekiej perspektywie czasowej. W sytuacji, kiedy w organizacji nie ma współpracy pomiędzy poszczególnymi komórkami (m.in. wzajemnych uzgodnień dotyczących sposobu realizowania strategii firmy) lub kiedy ta współpraca jest zakłócona, należy rozważyć, czy nie jest to w istocie pochodną sporu kompetencyjnego, do którego w sprawnie zarządzanej organizacji nie powinno dochodzić. Taki stan rzeczy, jak zaniedbania w jakiejkolwiek dziedzinie komunikacji, również wynikające z braku współpracy pomiędzy poszczególnymi komórkami firmy, nie może być z profesjonalnego punktu widzenia zaakceptowany (Szemborska, 1998). Niedopuszczalna jest alienacja komórki PR w ramach firmy, sytuacja, w której każdy departament żyje własnym życiem. Tak nie powinna wyglądać zintegrowana komunikacja organizacji z otoczeniem. Dobrą współpracę komórek marketingu, reklamy i public relations może zapewnić przede wszystkim właściwe umieszczenie tych działów W strukturze organizacji oraz sprawne zarządzanie przez szefa firmy. Być może zwiastunem zmian na lepsze jest fakt, że zarówno Polsat, jak i TVN w swoich strukturach mają osobę, której zadaniem jest usprawnić przepływ informacji między działami na rzecz skutecznej i funkcjonalnej komunikacji. Mam tutaj na myśli stanowisko brand managera produktu.

\section{PR w relacji $z$ aktorem i jego agentem}

Motyw niezrozumienia pracy PR-owca wybrzmiewa nie tylko w opisach relacji między PR-em a produkcją, ale również między PR-owcem danego serialu a aktorem bądź agentem go reprezentującym. Adamcio z Polsatu ma takie spostrzeżenia na temat współpracy $\mathrm{z}$ agentami:

W relacji z agentami gwiazd rozumienie mojej roli jest trochę lepsze, ale to nie znaczy, że zrozumienie to jest takie, jakiego bym oczekiwała. Brakuje mi w relacjach zawodowych z agentami takiej równorzędnej współpracy, pogadania, spotkania się. Wspólnego zastanowienia się co ja, jako osoba z Polsatu mogę zrobić, jak ja to widzę, oraz dowiedzieć się, co robi ten agent, jakie oni mają pomysły na promocję danego programu. Czyli zasadniczo jak możemy sobie wzajemnie pomóc. Tego niestety nie ma. Taka równorzędna i owocna współpraca ma miejsce bardzo rzadko. Są to przypadki, które mogę policzyć na palcach jednej ręki. Trudno mi nawiązać dobre relacje z agentami i szybko otrzymać informacje, których potrzebuję do 
mojej pracy. Czasami łatwiej mi się porozumieć z samym aktorem niż przez jego agenta, który jest bardzo często taką barierą w komunikacji hamującą moje działania. Moim zdaniem, taka postawa ze strony agenta nie jest dobra i często po prostu utrudnia mi pracę. Agenci są takimi menadżerami: my wysyłamy im emaile, oni to przekazują dalej do aktora i tyle. Nie ma czegoś takiego, że mogę liczyć na ich wsparcie; że mi pomogą. Oni tylko przekazują informacje i albo aktor odpowie, albo nie. To ja muszę o wszystko zabiegać, prosić, pamiętać, dopytywać. Jest to dla mnie trudne do zaakceptowania, że przy znanych nazwiskach pracują osoby o takiej etyce pracy, którzy w tak lekceważący sposób podchodzą do działań PR (Adamcio, 2021).

Agenci współpracujący z aktorami często nie priorytetyzują działań komunikacyjnych, ponieważ nie należą one do ich głównych obowiązków, które obejmują kontrakty, castingi, umowy i współpracę komercyjną. Agenci opiekują się $\mathrm{z}$ reguły dużą liczbą aktorów i z racji takiego obciążenia nie są w stanie otoczyć aktora indywidualną opieką również w sferze działań wizerunkowych, które z racji innych obowiązków agenta spychane są na sam dół ich listy priorytetów. Często też agenci zupełnie nie znają realiów prowadzenia działań komunikacyjnych, gdyż po prostu są ekspertami w zupełnie innej dziedzinie. Jednak te braki w ich rozumieniu działań PR-owych i znajomości podstaw działania rynku mediowego utrudniają pracę praktyka PR-u telewizyjnego. Odczuła to w swojej pracy również Sztych:

Z pewnością wyzwaniem w pracy PR-owca jest dbałość o interesy wielu różnych grup. Dziennikarz chce zrobić ciekawy materiał, aktor chce opowiedzieć o swojej roli w kluczowych dla swojej kariery mediach, producent nie chce zdradzić wszystkich ciekawostek serialu czy filmu. Połączenie tych potrzeb, bez szwanku dla kogokolwiek, wymaga zbudowania dobrych relacji i dużych umiejętności interpersonalnych. Czasem agenci gwiazd nie widzą korzyści ze współpracy z PR-owcem filmu czy serialu. Parokrotnie miałam sytuację pracy ręka $\mathrm{w}$ rękę $\mathrm{z}$ agentem aktora $\mathrm{i}$ wtedy efekt naszej pracy był dużo większy, bardzo korzystny zarówno dla gwiazdy, jak i stacji (Sztych, 2021).

Podobne odczucia ma były pracownik stacji TVN:

Agenci aktorscy często nie znają specyfiki działań promocyjnych. Miałam w swojej karierze takie sytuacje, że dosłownie godzinę przed drukiem wywiadu $\mathrm{z}$ aktorem, jego agent poprosił nagle o autoryza- 
cję layoutu. Taka sytuacja stawia PR-owca w bardzo trudnym położeniu. Może on wstrzymać publikację, ale tym samym naraża się wydawcy jednemu z największych czasopism kobiecych. Innym rozwiązaniem byłoby nie zgodzić się na akcept layoutu i w efekcie podpaść głównej aktorce serialu. Cokolwiek w takiej sytuacji PR-owiec zrobi, naraża się na nieprzyjemności albo ze strony redakcji, albo aktora, ryzykując tym samym swoją reputację. Jest to krzywdzące dla PR-owca, bo on swoich obowiązków dopełnił. W takim wypad$\mathrm{ku}$ jest to brak kompetencji ze strony agenta, który nie zna dynamiki rynku wydawniczego i nie wie, że, po pierwsze, redakcja nie ma obowiązku podsyłać aktorom layoutu do akceptacji, a po drugie - redakcja musi trzymać się konkretnych terminów wydawniczych i zmiany nie mogą być dokonane po ustalonym terminie na autoryzację. Agenci mają niekiedy nierealne oczekiwania od PR-owca stacji, co tylko świadczy o ich braku kompetencji w zakresie działań promocyjnych. Często nie są oni świadomi, jaki jest cykl wydawniczy konkretnych tytułów prasowych. Co więcej, agenci nie dostają prowizji od działań promocyjnych i z ich perspektywy nie są one warte zachodu. Są też bardziej zachowawczy, nie chcą ryzykować, podejmując działania promocyjne. Oni pracują z aktorem w bliskiej relacji, więc muszą pilnować interesu aktora, a nie stacji, bo inaczej aktor może sobie w każdej chwili zmienić agenta. Więc często PR-owiec stacji telewizyjnej i agent gwiazdy mają rozbieżne interesy (Anonim, 2021).

Jeśli aktor współpracuje nie tylko z agentem agencyjnym, ale również z agencją lub osobą zajmującą się komunikacją i działaniami z zakresu PR, to ta współpraca z ekspertem PR z ramienia stacji telewizyjnej układa się znacznie lepiej. Wygląda na to, że model pracy wypracowany na rynku amerykańskim gdzie standardem jest, że aktorzy oprócz agencji współpracują również z tzw. publicist (a potocznie określanym słowem flack), co możemy śmiało tłumaczyć jako specjalistę od komunikacji - jest bardzo funkcjonalny. Jednak nie jest to na razie powszechne w naszym rodzimym show-biznesie ${ }^{7}$.

W bezpośredniej relacji $\mathrm{z}$ aktorem specjalista PR z ramienia stacji telewizyjnej zmaga się ze stosunkowo małą możliwością egzekucji udziału aktorów w działaniach promocyjnych, które standardowo są wpisywane do załączników PR-owych umów przy danej produkcji. Adamcio zauważa, że jako PR-owiec nie znajduje się w dobrej pozycji do negocjacji:

7 Na temat public relations i show-biznesu polecam następujące źródła: Fitch (2017), Ziek (2016). 
Spotykałam się z niechęcią do współpracy ze strony nie tylko agentów, ale samych aktorów czy gwiazd. Zdarzają się sytuacje, że w ogóle nie mam jak prowadzić działań promocyjnych. Teraz zmagam się z taką trudną sytuacją przy serialu komediowym, gdzie dwójka aktorów grających główne role przebywa w Stanach Zjednoczonych. Kompletnie nie ma z nimi kontaktu, nie odpowiadają na maile i będą tam przez cały okres, w którym ja powinnam promować daną pozycję programową. Trzeci ważny aktor z głównej obsady nie udziela się, bo nie lubi i nie chce. Na koniec dnia naprawdę wszyscy chcemy dobrze i absolutnie nikt ze strony stacji nie chce działać na szkodę danego aktora. Jak aktor nie chce z kimś rozmawiać, to ja to rozumiem i nikogo nie chce do niczego zmuszać. Zawsze możemy wypromować program w sposób, który będzie pasował danemu aktorowi. Ale jakoś ten program trzeba wypromować, a do tego potrzebni są aktorzy. To produkcja podpisuje umowy z aktorami. Jako PR-owiec nie mam do tego wglądu, nie wiem jak konstruowane są umowy z aktorami i jak wyglądają zapisy dotyczące działań promocyjnych. W efekcie mam bardzo małe przełożenie na aktorów (Adamcio, 2021).

Brak chęci ze strony aktorów do współpracy w działaniach promocyjnych często wynika z braku zrozumienia charakteru, założeń i celowości takich działań. Aktorzy nie wiedzą np., że to, co przynosi serialom zasięg, to niekiedy siermiężnie wyglądające tygodniki telewizyjne. Nie znając dynamiki rynku prasowego, nie rozumieją oni, jakimi pobudkami kierują się PR-owcy, wybierając do współpracy konkretne pozycje prasowe. Motywowani chęcią współpracy jedynie z kolorowymi prestiżowymi magazynami, takimi jak „Twój Styl” czy "Vogue", aktorzy nie zdają sobie sprawy z tego, że takie tytuły mają realnie bardzo mały wpływ na zbudowanie zasięgu dla serialu. Często zatem aktorzy nie są zadowoleni z proponowanych im działań promocyjnych, co wynika z ich braku znajomości rynku telewizyjnego i prasowego. Sztych swoje doświadczenia w pracy z aktorami opisuje następująco:

Nie od razu i nie zawsze PR-owiec traktowany jest jako dodatkowa osoba do wsparcia, która za priorytet ma dobro serialu czy filmu, co jest równoznaczne z dobrem aktora. Myślę, że pokutuje taka obawa, że PR-owiec będzie chciał, na potrzeby promocji, zrobić z aktora kogoś innego, przebrać w ,inną skórę”. Natomiast w pracy PR-owca nie ma mowy o działaniach wbrew woli aktora. Są sytuacje, gdzie cele aktora i produkcji są rozbieżne, natomiast zadaniem PR-owca jest rozumienie tego i skupienie się na tym, co wspólne: promocja serialu, przedstawienie go widzom, zaciekawienie publiczności, opo- 
wiedzenie o postaciach. Myślę, że kluczowe w pracy z aktorem, ale z mojej perspektywy z każdym człowiekiem, jest dokładne poinformowanie, co będziemy robić, jakie pojawią się pytania, dlaczego te media a nie inne, jakich zdjęć użyjemy, jaki efekt chcemy uzyskać i na co będziemy mieć wpływ przed publikacją, a na co nie. To są kluczowe informacje, które pozwalają zrozumieć czasem nieoczywiste wybory PR-owca lub rozwiać obawy dotyczące tematu rozmowy lub medium (Sztych, 2021).

Były pracownik TVN podaje ciekawe przykłady ze swojej praktyki:

Aktorzy często widzą w osobie odpowiedzialnej za PR, kogoś, kto zmusza ich do rzeczy, których nie chcą robić. Wydaje mi się, że taka postawa wypływa, w dużej mierze, $\mathrm{z}$ niewiedzy i niepewności. Aktor nie wie, co go czeka, ani co z tego materiału wyjdzie. Odnoszą się do PR-u z rezerwą i boją się, że efekty nie będą satysfakcjonujące. Aktorzy często nie rozumieją też specyfiki rynku prasowego. Nie zdają sobie sprawy, że do promocji potrzebne są zdjęcia $\mathrm{z}$ uśmiechem, bo innych tygodniki telewizyjne nie zaakceptują na okładkę. Albo, że strój musi być w konkretnym kolorze, bo materiał będzie opublikowany na wiosnę, a to wymaga konkretnej oprawy kolorystycznej. Gazety preferują neutralne, gładkie stylizacje na okładkę, co często nie jest zgodne z wizją aktora na temat jego stylizacji do sesji zdjęciowej. Myślę sobie, że w decyzjach dotyczących przykładowo zdjęć wizerunkowych nie ma zaufania do specjalisty PR i zrozumienia, co stoi za jego decyzjami. Wspólnym interesem jest, żeby serial dobrze się obejrzał, miał wysoką oglądalność i aby komunikacja PR na temat danego serialu miała pozytywny oddźwięk w Internecie. Jednak nie zawsze aktor widzi to w takich barwach (Anonim, 2021).

Powszechne i dobrze znane specjalistom PR jest fałszywe wyobrażenie, wedle którego PR zajmuje się zakłamywaniem rzeczywistości. Jeśli chodzi o PR telewizyjny, aspekt ten mocno wybrzmiewa w relacjach z aktorami, gdzie PR-owcy są postrzegani jako manipulatorzy, osoby zajmujące się ukrywaniem prawdy, szkodzące interesom aktora poprzez nagłaśnianie kompromitujących dla niego faktów, a nie fachowcy i eksperci zajmujący się kompleksowym budowaniem wizerunku. W refleksjach praktyków PR-u telewizyjnego widać, że ocenia się ich jako osoby, które próbują podstępnie nakłonić aktorów do robienia rzeczy, których tamci nie chcą. Bardzo trudno jest przełamać ten krzywdzący dla fachu stereotyp PR-owca, który nie powinien mieć nic wspólnego z rzeczywistością. Według Olędzkiego, zarówno definicja public relations, jak i dorobek naukowy 
tej dyscypliny określają następujące wartości podstawowe dla public relations: szacunek i godność człowieka, uczciwość i rzetelność, prawda, wiarygodność, niezależność, szczerość i lojalność. Public relations powinno zatem pozostawać w zgodzie z normami etycznymi i zajmować się przekazywaniem jasnych i, przede wszystkim, rzetelnych informacji ze świadomością konsekwencji dokonywanych wyborów dla organizacji i środowiska społecznego (Olędzki, 2020, s. 21-24). Należy to rozumieć jako bezwzględnie obowiązujące założenie w prowadzeniu działalności PR, czyli zarządzaniu informacjami. Uczciwość, która jest niezbędnym technicznym warunkiem powodzenia przedsięwzięć PR, wynika przede wszystkim z ich specyfiki, którą wyznacza konieczność działania $\mathrm{w}$ długiej perspektywie. W szeroko zakrojonych i $\mathrm{z}$ natury rzeczy skomplikowanych poczynaniach komórki PR kłamstwo czy najogólniej mówiąc nierzetelność prędzej czy później ujrzą światło dzienne i przyniosą negatywne rezultaty. PR-owiec musi nieustannie czuwać nad tym, aby nie znaleźć się poza marginesem pozytywnego postrzegania ze strony opinii publicznej lub współpracowników, w tym przypadku dziennikarzy i aktorów. Zwykła ludzka uczciwość jest profesjonalnym wymogiem dla wszystkich działań PR.

Dla specjalisty PR z branży medialnej i biznesu rozrywkowego oczywiste jest, że przekłamania pojawiające się w mediach są częścią kultury pracy w tym sektorze. Pierwszą przyczyną takiego stanu rzeczy jest niewłaściwe (niekompetentne) komunikowanie się organizacji z dziennikarzami, drugą - to zdarzająca się wcale nierzadko, niekompetencja dziennikarza, oraz poszukiwanie sensacyjnych materiałów przez dziennikarzy sektora plotkarskiego. Dobry specjalista PR zlikwiduje skutki wynikające $\mathrm{z}$ większości negatywnych i możliwych do wystąpienia okoliczności, ale z reguły kosztem czasu, relacji i zasobów. Z tej cechy PR-u wynika, że kłamstwo jest w tej dziedzinie błędem profesjonalnym, a posługiwanie się półprawdami okazuje się zgubne w skutkach i w dłuższej perspektywie musi się również odbić negatywnie na wizerunku danego PR-owca, a także organizacji, dla której pracuje. Zachowania nieetyczne są po prostu nieopłacalne dla eksperta PR. Aktorzy zatem dość często niewłaściwie definiują lub wręcz deprecjonują public relations - ugruntowując negatywny image PR wśród tej grupy zawodowej.

Zarówno błędne rozumienie pracy PR-owca, jak i stosunkowo znaczący brak zaufania do tego zawodu wynika z braku edukacji. Przyczyny takiego stanu rzeczy upatruję w braku zajęć na kierunkach aktorskich przygotowujących aktorów do realiów rynku komercyjnego, w tym współpracy komercyjnej ze stacją telewizyjną lub producentem podczas promocji kontentu telewizyjnego. Na Wydziale Aktorskim Państwowej Wyższej Szkole Filmowej, Telewizyjnej i Teatralnej im. Leona Schillera w Łodzi, specjalizującej się w sztukach filmowych, nie prowadzi się zajęć $\mathrm{z}$ marketingu ani public relations $\mathrm{w}$ ramach przygotowania do zawodu (Tabowska, 2021). Podobna sytuacja ma miejsce w Aka- 
demii Sztuk Teatralnych im. S. Wyspiańskiego w Krakowie (Głowacka, 2021). W Akademii Teatralnej w Warszawie od 2017 roku oferuje się studentom zajęcia Rynek Pracy Aktora, ale w jego ramach porusza się jedynie zagadnienia takie, jak nagrywanie wizytówek; przygotowanie materiałów wideo (showreels), przebieg procesu castingowego, zasady tworzenia materiałów castingowych, czyli self tapes (Kurowski, 2021). Takie braki w kształceniu wybrzmiewają w relacji aktora Sebastiana Dudały, który ukończył Wydział Aktorski Akademii Teatralnej w Warszawie w 2014 roku:

Kiedyś kształcono aktorów $\mathrm{z}$ przeświadczeniem, że na pewno będą mieli pracę $\mathrm{w}$ teatrze. I takie przekonanie mieli też studenci $\mathrm{z}$ mojego roku, że wszyscy bez problemu znajdziemy pracę. Ale to były realia jeszcze $\mathrm{z}$ czasów teatru zespołowego. Akademia Teatralna, moim zdaniem, nie zauważyła zmian w branży. Teraz aktor wychodzi na rynek, który się kompletnie zmienił - jest agresywny, istnieje duża konkurencja, a na dodatek jest pełen amatorów. Ta szkoła wychowała nas pod kątem fachu aktorskiego, ale jak wyszliśmy na rynek, to większość osób z mojego rocznika zadała sobie pytanie, co teraz? Nie mieliśmy zupełnie żadnego przygotowania do aktorstwa jako biznesu, realiów branżowych. Niektórzy oczywiście dostają pracę od razu, bo rynek ich zasysa, ale co z innymi? Nikt mi nie wytłumaczył mechanizmów, które rządzą rynkiem. Rola PR-owca jest mi osobiście nieznana. Nie mam zbyt dużej świadomości tej funkcji. Mi PR kojarzy się przede wszystkim z polityką (Dudała, 2021).

Public relations to używany coraz częściej termin, którego interpretacja i rozumienie są równie często błędne, jak poprawne. Wypaczenia w użyciu pojęcia public relations, aby ukryć w nim działania nieetyczne, nieuczciwe i manipulację, w konsekwencji prowadzą do negatywnego postrzegania nie tylko terminu, ale $\mathrm{i}$ wartości, jakie on niesie. $\mathrm{W}$ efekcie, pracownicy PR w telewizji zmagają się z pejoratywnym obrazem swojego zawodu, który przez laików kojarzony jest z działalnością potocznie nazywaną czarnym PR-em, często właśnie kojarzonym z polityką. Działania tzw. czarnego PR-u są najczęściej inspirowane pobudkami politycznymi, co oznacza, że stoją za nimi osoby uczestniczące w kampaniach wyborczych lub sztaby wyborcze. Mamy zatem do czynienia z ukrytą działalnością dyfamacyjną nazywaną popularnie czarnym PR-em. Nasuwa się tu oczywisty wniosek: to właśnie najczęściej barbarzyńskie metody walki politycznej kojarzone są z zawodem PR-owca i dlatego psują reputację pracowników PR z innych branż. 


\section{Wnioski}

Zjawiska przedstawione $\mathrm{w}$ artykule zaczerpnięto wywiadów ze specjalistami PR ze stacji TVN i Polsat przeprowadzonych w 2021 roku. Materiały źródłowe, czyli wypowiedzi pracowników PR-u telewizyjnego, cytowane w tym artykule z pewnością dostarczają ciekawych i unikatowych informacji na temat branży telewizyjnej. Jednak nie powinny być one traktowane jedynie jako anegdoty branżowe. Chciałabym bowiem rozważyć wartość, jaką ma autorefleksyjny dyskurs praktyków branżowych dla badaczy studiów medioznawczych. Refleksje praktyków PR w telewizji na temat ich własnej pracy i kontekstu, w jakim się znajdują, dostarczają empirycznych materiałów umożliwiających wyjście poza klasyczne postrzeganie działań promocyjnych, czyli ich analizę jedynie przez pryzmat efektów i skuteczności. Dzięki spojrzeniu na działania PR w telewizji z punktu widzenia praktyków badacze mają szansę poznać kulturę pracy tego zawodu, jego instytucjonalne usytuowanie, co z kolei pozwala na zaznajomienie się z panującymi w branży rozrywkowej relacjami i zależnościami.

Opisane przypadki są jedynie wycinkiem realiów pracy w telewizji, jednak przedstawione procesy są wystarczające, aby wyciągnąć pewne uogólnione wnioski. Z autorefleksyjnej narracji dowiadujemy się, że PR-owcy w telewizji mają złe samopoczucie z powodu niezrozumienia ich roli przez inne zawody w środowisku medialnym. Wbrew logice, środowisko branżowe często postrzega PR jako podrzędną funkcję marketingu. To spór pozbawiony sensu, ale będący faktem i brzemienny w negatywne skutki. Specjaliści PR w telewizji kojarzeni są też z działaniami takimi, jak manipulacja, wykorzystywanie wiedzy i narzędzi PR na niekorzyść osób zainteresowanych. Kojarzenie nieetycznych zachowań i ukrywanie ich pod płaszczem PR dokonało się za sprawą polityków, których działania utrwaliły negatywny stereotyp PR-owca. Niestety, stereotypy te są nadal obecne w powszechnej świadomości, odnosząc się również do PR-u telewizyjnego, który nie ma nic wspólnego z nieuczciwymi praktykami znanymi z przepychanek politycznych.

Wniosek nasuwający się po analizie autorefleksyjnej narracji specjalistów PR pracujących w strukturach telewizji naziemnej to potrzeba edukowania otoczenia, w tym przypadku branży telewizyjnej i związanych z nią zawodów, czym jest PR. Lepsze zrozumienie działań PR wśród producentów, aktorów, ich agentów, ale też dziennikarzy może jedynie usprawnić relacje w branży i przyczynić się do bardziej płynnej komunikacji pomiędzy przedstawicielami różnych zawodów. Edukacja w zakresie roli PR w szeroko pojętym show-biznesie powinna obejmować nauczanie na studiach kierunkowych, tematyczne warsztaty lub szkolenia w ramach przyuczania do zawodu młodych profesjonalistów, takich jak chociażby dziennikarze czy aktorzy. Równie dużo pracy, co szerzenie wiedzy o znaczeniu public relations, trzeba jeszcze wykonać nad postrzeganiem 
środowiska PR i jego odbiorem w branży telewizyjnej. Dominujące dotychczas stereotypy działają na niekorzyść praktyków PR, co z kolei szkodzi całej branży. Starania praktyków PR mogą zostać w pełni doceniane, a potencjał działań z zakresu komunikacji w pełni wykorzystany jedynie w momencie, kiedy negatywny obraz tego fachu przestanie być powszechnie obowiązującym.

Zarysowany przeze mnie i proponowany kierunek badań nad telewizją musi być rozwijany i uzupełniany przez kolejne, empirycznie osadzone analizy poszczególnych przypadków i wynikające z nich, odpowiednio zebrane, wnioski. Badania przedstawione w niniejszym artykule stanowią w mojej ocenie asumpt dla nowych perspektyw badawczych w obrębie studiów medioznawczych. Badania sektora produkcji materiałów promocyjnych, dotychczas pomijane w rodzimych studiach medioznawczych, oferują lepszy, pełniejszy opis i pomoc w zrozumieniu działań sektora kreatywnego branży telewizyjnej. W tym właśnie widzę sens prowadzenia badań etnograficznych jako uzupełnienie dotychczasowych perspektyw i wzbogacenie naszej wiedzy na temat kultury audiowizualnej, socjologii twórczości oraz kultury pracy w sektorze kreatywnym. Do osiągnięcia tych celów, zgromadzenia niezbędnej wiedzy posłużyć mogą pogłębione wywiady z praktykami z branży. Nie sposób znaleźć tej wiedzy w innych źródłach.

\section{Bibliografia}

Adamcio, R. (2021, kwiecień 21). Wywiad osobisty.

Baumann, J. (2007). Television Marketing - Characteristics, Instruments and Impact. VDM Verlag Dr. Mueller E.K.

Bobińska, A. (2000). Promocja jako element marketingu mix. W: J. Pindakiewicz, (red.), Podstawy marketingu. Warszawa: Oficyna Wydawnicza Szkoły Głównej Handlowej.

Caldwell, J.T. (2009a). Cultures of Production: Studying Industry's Deep Texts, Reflective Rituals and Managed Self-Disclosures. In: J. Holt, A. Perren, (eds.), Media Industries: History, Theory, and Method. Oxford: Wiley-Blackwell.

Caldwell, J.T. (2008). Production Culture: Industrial Reflexivity and Critical Practice in Film and Television. Durham: Duke University Press.

Caldwell, J.T. (2009b). How Producers 'Theorize': Shoot-outs, Bake-offs and Speed-Dating. In: R. Hammer, D. Kellner, (eds.), Media/Cultural Studies: Critical Approaches. New York: Peter Lang.

Czarnowski, P. (1997). Dzisiaj i za kilka lat w public relations, dodatek do Gazety Wyborczej, z dn. 21.04.1997.

Cenker, E.M., (2000). Public Relations. Poznań: Wydawnictwo Wyższej Szkoły Bankowej. 
Domański, T., Kowalski, P. (2000). Marketing dla menedżerów. Warszawa-Łódź: Wydawnictwo Naukowe PWN.

Dudała, S. (2021, kwiecień 16). Wywiad osobisty.

Eastman, S.T. (2000). Orientation to Promotion and Research. In: S.T. Eastman, Research in Media Promotion. Mahwah, New Jersey, London: Lawrence Erlbaum Associates.

Eastman, S.T., Ferguson, D.A., Klein, R. (2006). Media Promotion \& Marketing for Broadcasting, Cable \& the Internet. New York: Routledge.

Fitch, K. (2017). „Seeing 'the unseen hand': Celebrity, promotion and public relations." Public Relations Inquiry, 6 (2), s. 157-169.

Głowacka, K. (2021, kwiecień 15). Wiadomość prywatna.

Grainge, P., Johnson, C. (2015). Promotional Screen Industries. New York: Routledge. Gray, J. (2010), Show Sold Separately: Promos, Spoilers, and Other Media Paratexts. New York-London: New York University Press.

Jupowicz-Ginalska, A. (2010a). Marketing medialny. Warszawa: Difin.

Jupowicz-Ginalska, A. (2010b). Syndrom „wirującego bąka”, czyli rzecz o autopromocji medialnej. Studia Medioznawcze, 3 (42), s. 37-52.

Jupowicz-Ginalska, A. (2013). Efektywna promocja własna jako źródło wizerunkowego sukcesu organizacji medialnej - na przykładzie TVN S.A. Zeszyty Naukowe Uniwersytetu Przyrodniczo-Humanistycznego w Siedlcach, 25 (98), s. $383-402$.

Jupowicz-Ginalska, A. (2015). Serwisy informacyjne a autopromocja środków przekazu - na przykładzie „Faktów” TVN. Zeszyty Prasoznawcze, 3 (223), s. 688-703.

Kurek, K. (2021, kwiecień 14). Wywiad osobisty.

Kurowski, K. (2021, kwiecień 16). Wiadomość prywatna.

Lotz, A. D. (2007). The Promotional Role of the Network Upfront Presentations in the Production of Culture. Television \& New Media, 8 (1), s. 3-24.

Mann, D. (2009). It's Not TV, It's Brand Management TV. The Collective Author(s) of the Lost Franchise. In: V. Mayer, M.J. Banks, J.T. Caldwell, (eds.), Production Studies: Cultural Studies of Media Industries. New York-London: Routledge.

Okoński, G., Wójcik., Ł., Szpilska, M. (2018). Informacja o Zawodzie. Specjalista do Spraw Public Relations (243203). Ministerstwo Rodziny, Pracy i Polityki Społecznej, Departament Rynku Pracy. Warszawa: Wydawnictwo Naukowe Instytutu Technologii Eksploatacji - PIB

Olędzki, J., Tworzydło, D. (red.) (2009), Leksykon Public Relations. Rzeszów: Wydawnictwo Newsline.

Olędzki, J. (red.) (2020). Standardy profesjonalnego public relations. Warszawa: Wydawnictwo Naukowe UKSW.

Piątkowski, W. (2011). Marketing Telewizji, czyli dlaczego tylko niektóre seriale odnoszą sukces. W: Post-soap. Nowa generacja seriali telewizyjnych a polska widownia. Warszawa: Wydawnictwo Naukowe Scholar.

Pluszyńska, A. (2015). Zarządzanie własnością intelektualną w agencji reklamowej - wstęp do zagadnienia, Zarzadzanie Mediami, 3 (1), s. 45-57.

Ries, A., Ries, L. (2004). Upadek reklamy i wzlot public relations. Warszawa: PWE Polskie Wydawnictwo Ekonomiczne. 
Rozwadowska, B., (2009). Public relations. Teoria, praktyka, perspektywy. Warszawa: Wydawnictwo Studio EMKA.

Skwarek, O. (2021, kwiecień 16). Wywiad osobisty.

Smith, R.D. (2021). Strategic Planning for Public Relations. Routledge.

Szemborska, E. (1998). Komunikacja przedsiębiorstwa z otoczeniem. W: Bielawski, P. Materiały z Seminarium Komunikacja Społeczna w Zarzadzaniu (Public Relations) dla prezesów spótek Grupy Kapitałowej KGHM Polska Miedź S.A., Lubin-Kudowa Zdrój.

Szewczyk, Ł. (2011). Polska: 26,6 mln widzów płatnej TV. Pobrano z: http:// media2.pl/media/73956-Polska-26,6-mln-widzow-platnej-TV.html (data dostępu: 10.05.2021).

Stopczyńska, K. (2001). Public relations jako narzędzie komunikowania się firmy z otoczeniem. W: Ślusarczyk, S., Świda, J., Tworzydło, D. (red.). Public relations w kształtowaniu pozycji konkurencyjnej organizacji. Rzeszów: Wyższa Szkoła Informatyki i Zarządzania w Rzeszowie.

Sztych, P. (2021, kwiecień 6). Wywiad osobisty.

Tabowska, M. (2021, kwiecień 15). Wiadomość prywatna.

TeleKabel kwiecień 2020, s. 27.

Weiner, M. (2006). Unleashing the Power of PR: A Contrarian's Guide to Marketing and Communication. Chichester: Wiley.

Wirtualne Media, (2020a). Przez epidemię wptywy reklamowe Polsatu zmalaty o 34 proc. „Poprawa nastrojów rynkowych w czerwcu i lipcu”. Pobrano z: https:// www.wirtualnemedia.pl/artykul/polsat-telewizja-wplywy-zmalaly-o-34-procpoprawa-nastrojow-rynkowych-w-czerwcu-i-lipcu (data dostępu: 10.05.2021).

Wirtualne Media, (2020b). Reklamodawcy ograniczaja wydatki w telewizji. Budżety na poczatku kwietnia spadty o 25 proc. Pobrano z: https://www.wirtualnemedia. $\mathrm{pl} /$ artykul/wplywy-reklamowe-w-telewizji-spadly-o-25-proc-analiza (data dostępu: 10.05.2021).

Wirtualne Media, (2021a). Rynek kanałów filmowo-serialowych w 2020 roku wzróst o 9 proc. Liderem TVP Seriale, Pobrano z: https://www.wirtualnemedia.pl/artykul/ogladalnosc-kanaly-filmowe-i-serialowe-2020 (data dostępu: 10.05.2021).

Wirtualne Media, (2021b). Rynek kanałów filmowo-serialowych w I kwartale wzróst o 15 proc., Stopklatka wyprzedziła TVP Seriale. Pobrano z: https://www.wirtualnemedia.pl/artykul/ogladalnosc-kanaly-filmowe-i-serialowe-i-kwartal-2021stopklatka (data dostępu: 10.05.2021).

Wirtualne Media, (2021c). TVN zwalnia, bo Discovery ucierpiało $w$ epidemii. Oszczędności w TVN24 ze strata dla dziennikarstwa. Pobrano z: https://www. wirtualnemedia.pl/artykul/tvn-zwolnienia-dziennikarze-praca (data dostępu: 10.05.2021).

Wirtualne Media, (2021d). Stawomir Gotębiowski po 20 latach odchodzi z TVN. Redukcje $w$ marketingu. Pobrano z: https://www.wirtualnemedia.pl/artykul/ slawomir-golebiowski-po-20-latach-odchodzi-z-tvn-redukcje-w-departamenciemarketingu (data dostępu: 10.05.2021).

Wirtualne Media, (2021e). Dwutygodniki people stracity 28 proc. „Flesz” $i$,Gala” z największymi spadkami. Pobrano z: https://www.wirtualnemedia.pl/artykul/ 
dwutygodniki-people-stracily-28-proc-flesz-i-gala-z-najwiekszymi-spadkami (data dostępu: 10.05.2021).

Wróblewska, A., (2016). Production Studies w Polsce - stan badań. Panoptikum. Film / Nowe Media / Sztuki Wizualne, (16).

Wyatt, J. (1994). High Concept: Movies and Marketing in Hollywood. Austin: University of Texas Press.

Ziek, P. (2016). Cultivating Celebrity Public Relations. Celebrity Studies, 7 (1), s. $122-124$. 